LA-14356-PR

Progress Report

Approved for public release;

distribution is unlimited.

2006 Toxic Chemical Release Inventory

Report for the Emergency Planning and

Community Right-to-Know Act of 1986,

Title III, Section 313 
Edited by Hector Hinojosa, Group IRM-CAS.

The four most recent reports in this unclassified series are LA-14096-PR, LA-14186-PR, LA-14237-PR, and LA-14313-PR.

Los Alamos National Laboratory, an affirmative action/ equal opportunity employer, is operated by Los Alamos National Security, LLC, for the National Nuclear Security Administration of the U.S. Department of Energy under contract DE-AC52-06NA25396.

This report was prepared as an account of work sponsored by an agency of the U.S. Government. Neither Los Alamos National Security, LLC, the U.S. Government nor any agency thereof, nor any of their employees make any warranty, express or implied, or assume any legal liability or responsibility for the accuracy, completeness, or usefulness of any information, apparatus, product, or process disclosed, or represent that its use would not infringe privately owned rights. Reference herein to any specific commercial product, process, or service by trade name, trademark, manufacturer, or otherwise does not necessarily constitute or imply its endorsement, recommendation, or favoring by Los Alamos National Security, LLC, the U.S. Government, or any agency thereof. The views and opinions of authors expressed herein do not necessarily state or reflect those of Los Alamos National Security, LLC, the U.S. Government, or any agency thereof. Los Alamos National Laboratory strongly supports academic freedom and a researcher's right to publish; as an institution, however, the Laboratory does not endorse the viewpoint of a publication or guarantee its technical correctness. 
LA-14356-PR

Progress Report

Issued: December 2007

2006 Toxic Chemical Release Inventory Report

for the Emergency Planning and Community

Right-to-Know Act of 1986, Title III, Section 313

Ecology and Air Quality Group (ENV-EAQ)

- Los Alamos 



\section{CONTENTS}

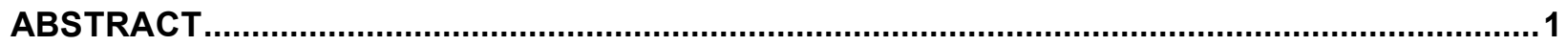

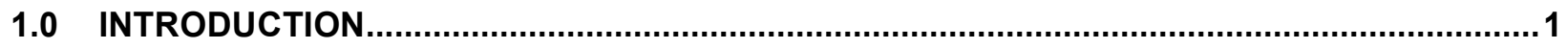

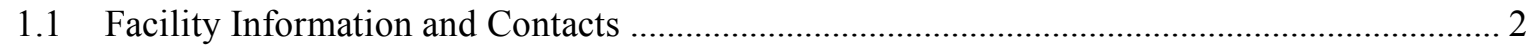

2.0 ACTIVITY DETERMINATIONS, EXEMPTIONS, AND QUALIFIERS ................................... 3

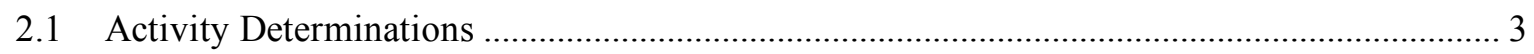

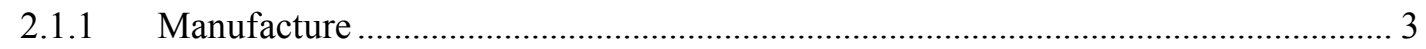

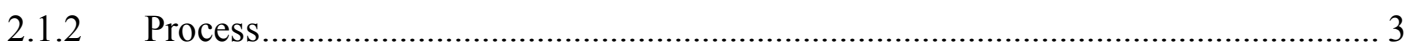

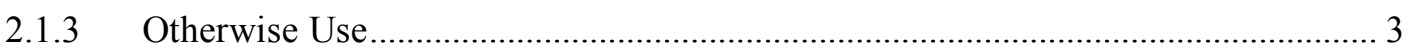

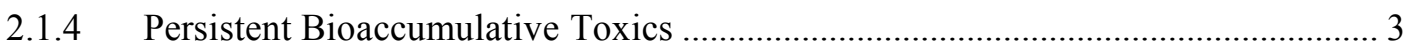

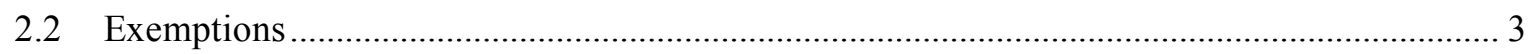

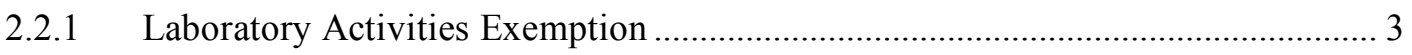

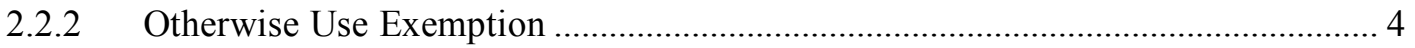

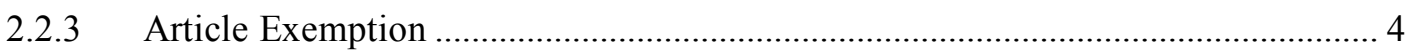

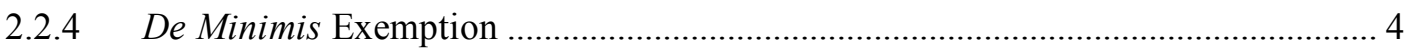

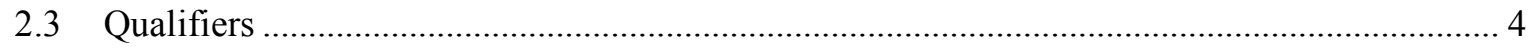

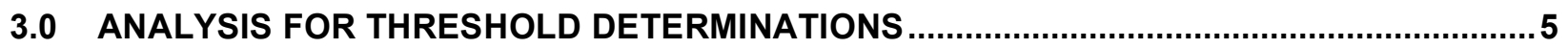

3.1 Threshold Determinations for Chemical Use .......................................................................... 5

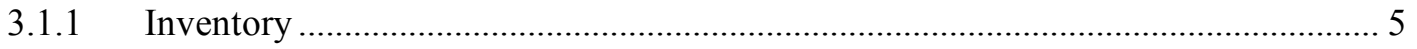

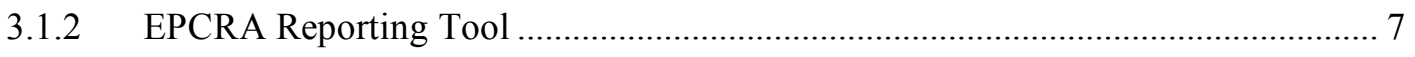

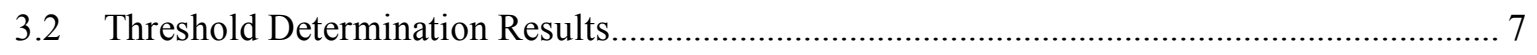

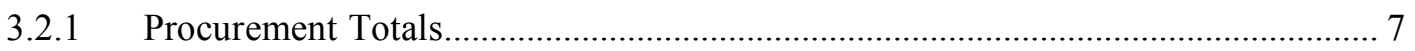

4.0 ADDITIONAL EVALUATION OF CERTAIN TOXIC CHEMICALS …...................................... 8

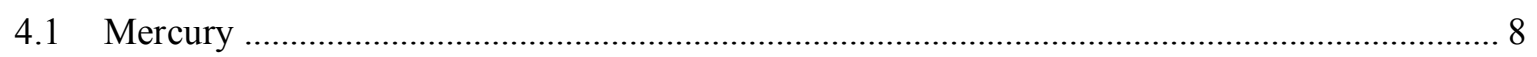

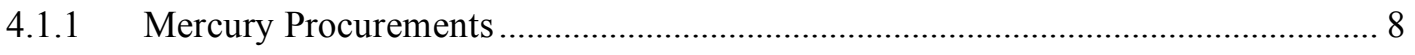

4.1.2 Los Alamos Neutron Science Center Shutter System ............................................. 9

4.1.2.1 Spallation Neutron Source Target Development Experiment ............................. 9

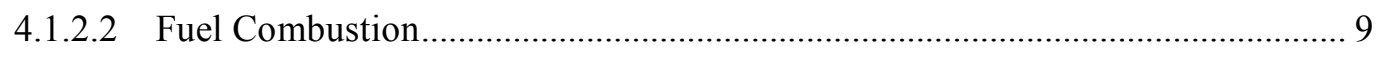

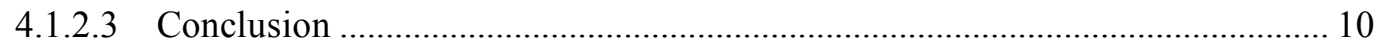

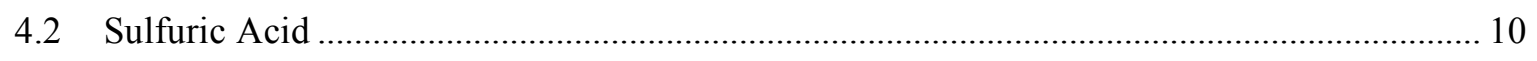

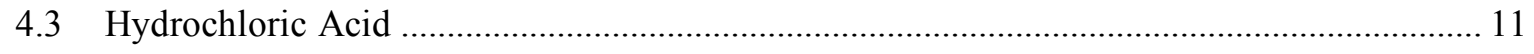

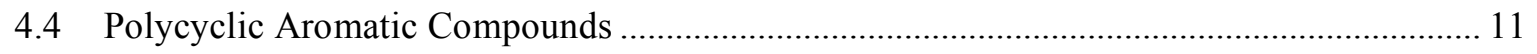

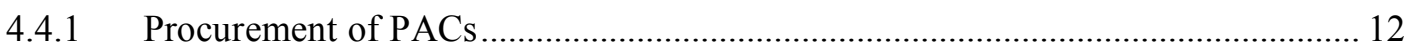

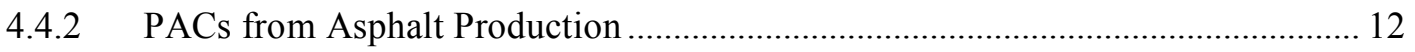

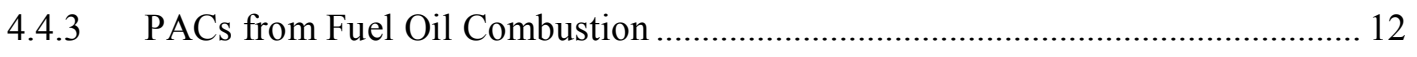

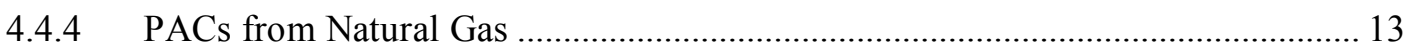

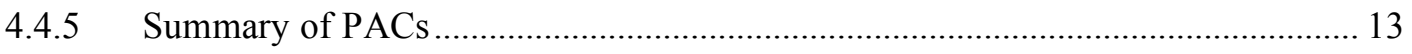

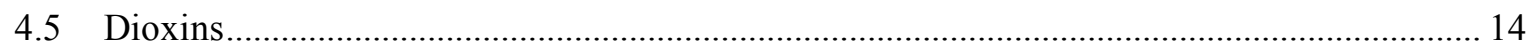

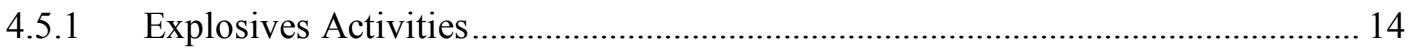

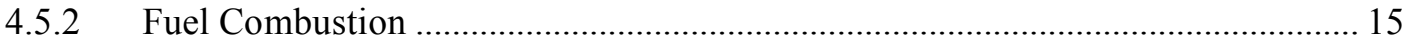

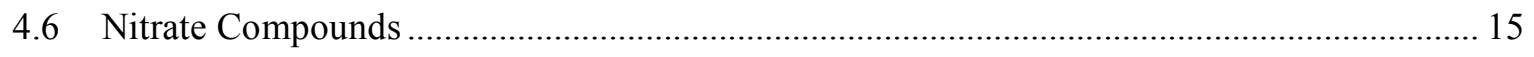




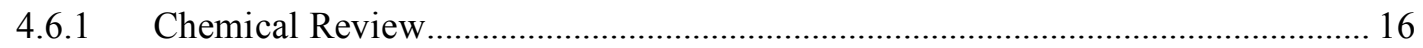

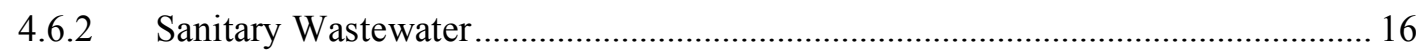

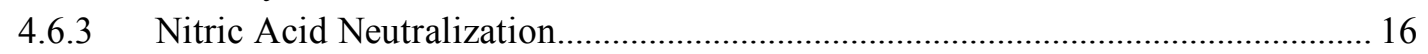

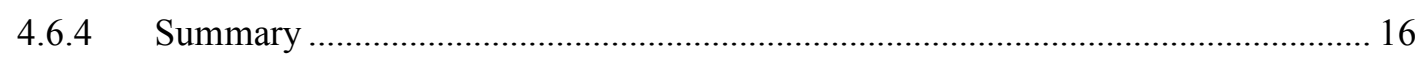

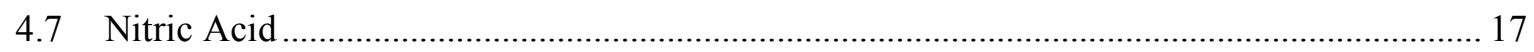

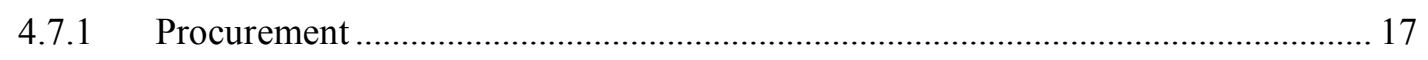

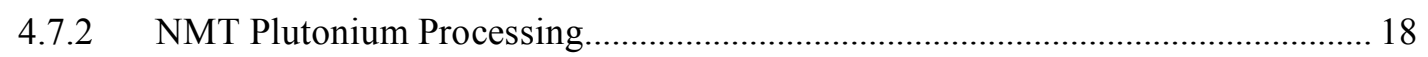

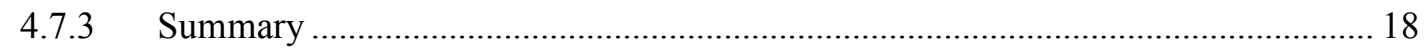

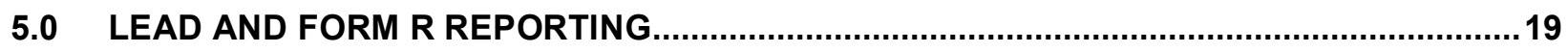

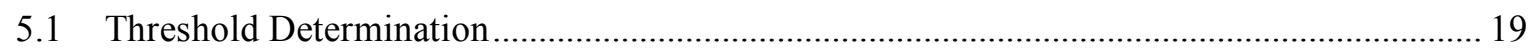

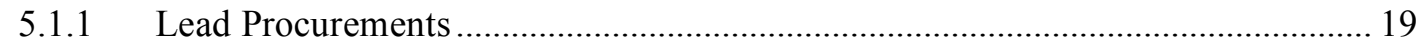

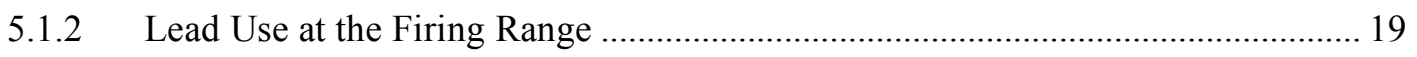

5.1.3 Lead from Fuel Combustion ............................................................................ 20

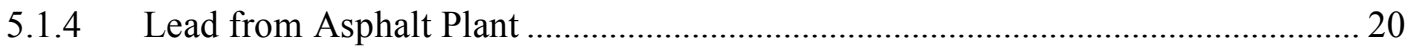

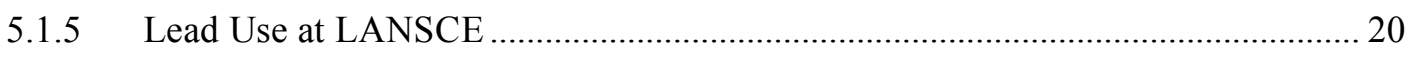

5.1.6 Other LANL Operations Using Lead and Lead Compounds ................................. 21

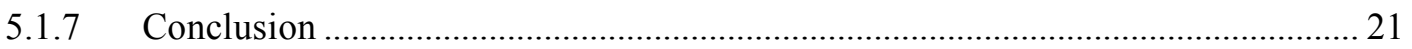

5.2 Environmental Releases and Offsite Disposal .................................................................. 22

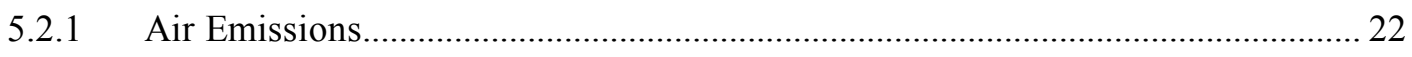

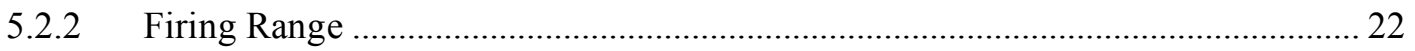

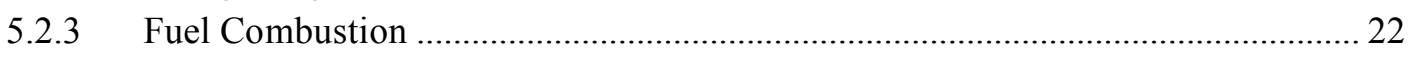

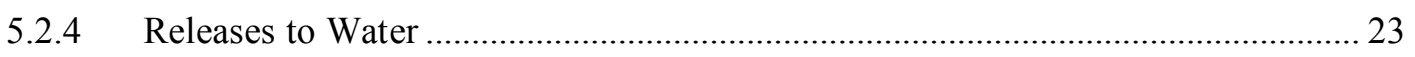

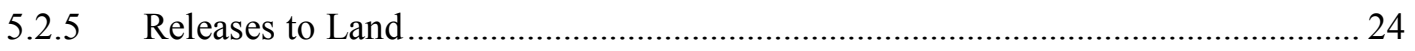

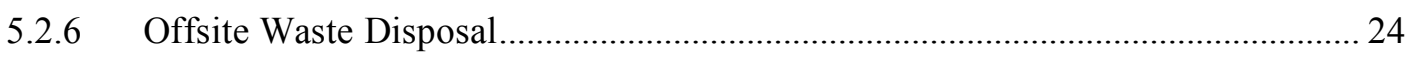

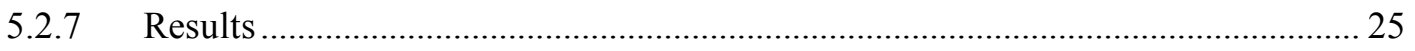

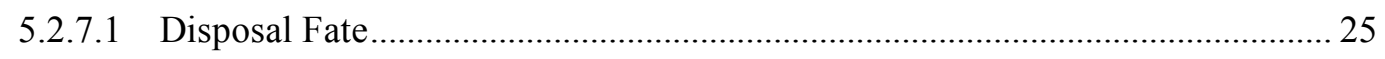

5.3 Other Information Provided on Form R Report .................................................................. 26

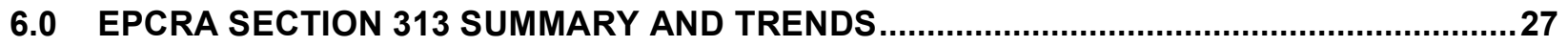

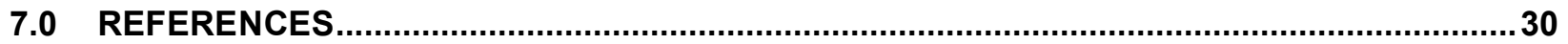

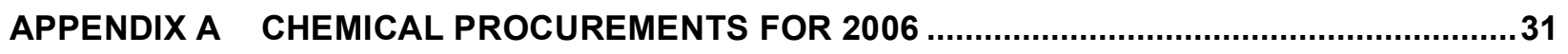

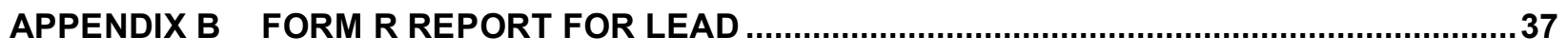




\section{Figures}

Figure 3-1 Flowchart process of analysis for EPCRA Section 313 reporting .................................... 6

Figure 6-1 Trends in LANL's reported releases to EPA TRI. .......................................................... 29

Figure 6-2 Trends in TRI reportable chemical use at LANL ........................................................... 29

\section{Tables}

Table 2-1 Examples of EPCRA Section 313 Chemical Qualifiers................................................... 5

Table 3-1 Top 10 EPCRA Section 313 Chemicals Procured in 2006 ............................................... 8

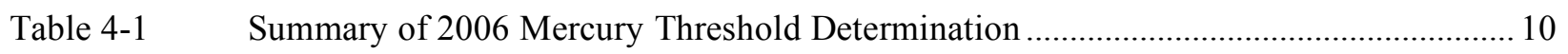

Table 4-2 Sulfuric Acid Threshold Determination for 2006 ........................................................... 11

Table 4-3 LANL 2006 Threshold Determinations for PACs and Benzo(g,h,i)perylene ................... 13

Table 4-4 Dioxin Threshold Determination for 2006 .................................................................. 15

Table 4-5 Summary of Nitrate Compounds at LANL in 2006 .................................................... 17

Table 4-6 Summary of Nitric Acid Use at LANL in 2006............................................................. 19

Table 5-1 Summary of Threshold Determination for Lead and Lead Compounds for 2006............. 22

Table 5-2 Lead Air Emissions from LANL in 2006..................................................................... 23

Table 5-3 Lead Releases to Water in 2006 from LANL NPDES Outfalls ........................................24

Table 5-4 Summary of Waste Disposal Facilities Receiving LANL Waste in 2006 ........................26 


\title{
2006 Toxic Chemical Release Inventory Report for the \\ Emergency Planning and \\ Community Right-to-Know Act of 1986, Title III, Section 313
}

by

Ecology and Air Quality Group (ENV-EAQ)

\begin{abstract}
For reporting year 2006, Los Alamos National Laboratory (LANL or the Laboratory) submitted Form R reports for lead as required under the Emergency Planning and Community Right-to-Know Act (EPCRA) Section 313. No other EPCRA Section 313 chemicals were used in 2006 above the reportable thresholds. This document was prepared to provide a description of the evaluation of EPCRA Section 313 chemical use and threshold determinations for LANL for calendar year 2006, as well as to provide background information about data included on the Form $\mathrm{R}$ reports.

Section 313 of EPCRA specifically requires facilities to submit a Toxic Chemical Release Inventory Report (Form R) to the U.S. Environmental Protection Agency (EPA) and state agencies if the owners and operators manufacture, process, or otherwise use any of the listed toxic chemicals above listed threshold quantities. EPA compiles this data in the Toxic Release Inventory database. Form R reports for each chemical over threshold quantities must be submitted on or before July 1 each year and must cover activities that occurred at the facility during the previous year.

In 1999, EPA promulgated a final rule on persistent bioaccumulative toxics (PBTs). This rule added several chemicals to the EPCRA Section 313 list of toxic chemicals and established lower reporting thresholds for these and other PBT chemicals that were already reportable. These lower thresholds became applicable in reporting year 2000. In 2001, EPA expanded the PBT rule to include a lower reporting threshold for lead and lead compounds. Facilities that manufacture, process, or otherwise use more than $100 \mathrm{lb}$ of lead or lead compounds must submit a Form R.
\end{abstract}

\subsection{INTRODUCTION}

On April 21, 2000, President Clinton signed Executive Order (EO) 13148, which requires all federal facilities to comply with the provisions of the Emergency Planning and Community Right-to-Know Act (EPCRA), or Title III of the Superfund Amendments and Reauthorization Act of 1986. EO 13148 supersedes EO 12856 of 1995. Section 313 of EPCRA specifically requires facilities to submit a Toxic 
Chemical Release Inventory Report (Form R) to the U.S. Environmental Protection Agency (EPA) and state agencies if the owners and operators manufacture, process, or otherwise use any of the listed toxic chemicals above listed threshold quantities. On October 19, 1999, EPA promulgated a final rule on persistent bioaccumulative toxics (PBTs). This rule added several chemicals to the EPCRA Section 313 list of toxic chemicals and established lower reporting thresholds for these and other PBT chemicals that were already reportable under EPCRA Section 313. These lower thresholds became applicable in reporting year 2000. On January 17, 2001, the PBT rule was amended to include lead and lead compounds. The rule lowered the reporting threshold for lead and lead compounds to $100 \mathrm{lb}$. The lower threshold for lead became applicable in reporting year 2001.

EPA compiles the data submitted on the Form R reports in a Toxic Release Inventory (TRI) database. The TRI database provides the public with information on the releases of EPCRA Section 313 chemicals in their communities as well as provides EPA with release information to assist in determining the need for future regulations (http://www.epa.gov/tri/). Form R must be submitted on or before July 1 each year and must cover activities that occurred at the facility during the previous calendar year. Even though federal facilities were not required to report under EPCRA Section 313 until 1995, Los Alamos National Laboratory (LANL) had been voluntarily reporting under EPCRA Section 313 since 1987.

For reporting year 2006, the Laboratory submitted Form R reports for lead. No other EPCRA Section 313 chemicals were used in 2006 above the reportable thresholds. Toxic chemicals used in exempt activities as defined by the regulation are excluded from the threshold determinations and release calculations. Descriptions of these exempt activities are included in Section 2.2 of this report.

This report summarizes the data evaluation, exemption analysis, activity determinations, and threshold determinations for toxic chemical use at the Laboratory in 2006, and describes the environmental release data reported on the Form $\mathrm{R}$ reports. Individual sections for certain toxic chemicals used at the Laboratory are included in this report. Appendix A presents a summary table of EPCRA Section 313 chemicals procured at the Laboratory in 2006. Appendix B includes copies of Form R reports submitted to EPA and the New Mexico Environment Department.

\subsection{Facility Information and Contacts}

LANL is located at latitude of $35^{\circ} 49^{\prime} 51^{\prime \prime}$ and longitude of 106 $14^{\prime} 15^{\prime \prime}$ in Los Alamos County, New Mexico. During 2006, the Laboratory was owned by the U.S. Department of Energy (DOE) and operated by the University of California (UC) from January 1-May 31 and operated by the Los Alamos National Security, LLC (LANS) for the period June 1-December 31. Because the Laboratory was owned and operated by different entities in 2006, duplicate Form Rs were submitted by the DOE and LANS.

Facility information is as follows:

- $\quad$ LANL

* TRI facility identification number: 87545LSLMSLOSAL

* LANL technical contact: Mr. Steve Story at (505) 665-2169

* LANL public contact: Ms. Lorrie Bonds Lopez at (505) 667-0216 
- Los Alamos DOE complex

* TRI facility identification number: 87544SDLSL52835

* DOE technical and public contact: Mr. Gene Turner at (505) 667-5794

\subsection{ACTIVITY DETERMINATIONS, EXEMPTIONS, AND QUALIFIERS}

\subsection{Activity Determinations}

EPCRA Section 313 chemical usage is evaluated against three activity determinations. For listed chemicals that are not PBTs, the thresholds are described below.

\subsubsection{Manufacture}

The term manufacture means to produce, prepare, compound, or import an EPCRA Section 313 chemical. The term manufacture also includes coincidental production of an EPCRA Section 313 chemical as a result of the manufacture, processing, otherwise use, or treatment of other chemical substances. The threshold for reporting manufactured chemicals is $25,000 \mathrm{lb}$.

\subsubsection{Process}

The term process means the preparation of a listed EPCRA Section 313 chemical, after its manufacture, for distribution in commerce. Processing is usually the intentional incorporation of an EPCRA Section 313 chemical into a product. The threshold for reporting processed chemicals is $25,000 \mathrm{lb}$.

\subsubsection{Otherwise Use}

The term otherwise use usually means any use of an EPCRA Section 313 chemical, including in a mixture or trade name product or waste that is not covered by the terms manufacture or process. The threshold for reporting otherwise use chemicals is $10,000 \mathrm{lb}$.

\subsubsection{Persistent Bioaccumulative Toxics}

For the subset of chemicals listed as PBTs, lower reporting thresholds have been established for individual chemicals ranging from $100 \mathrm{lb}$ to 0.1 gram. These lower thresholds apply to each of the activity determinations: manufacture, process, and otherwise use. Although the threshold for each activity is the same, each chemical must be evaluated against the activity determinations to determine in which activity the chemical is used. Threshold determinations for PBTs are evaluated separately against the manufacture, process, and otherwise use activities described above.

\subsection{Exemptions}

Exemptions from EPCRA Section 313 toxic chemical reporting applicable to the Laboratory are discussed below.

\subsubsection{Laboratory Activities Exemption}

EPCRA Section 313 chemicals that are manufactured, processed, or otherwise used in laboratory activities at a covered facility under the direct supervision of a technically qualified individual do not 
have to be considered for threshold determinations and release calculations. However, pilot plant scale, specialty chemical production, or the use of chemicals for laboratory support activities do not qualify for this laboratory activities exemption.

\subsubsection{Otherwise Use Exemption}

Certain activities involving EPCRA Section 313 chemicals qualify as otherwise used and are specifically exempted. These include the following:

- otherwise use as a structural component of the facility,

- otherwise use in routine janitorial or facility grounds maintenance,

- personal uses by employees or other persons,

- otherwise use of products containing EPCRA Section 313 chemicals for the purpose of maintaining motor vehicles operated by the facility, or

- otherwise use of EPCRA Section 313 chemicals contained in intake water (used for processing or non-contact cooling) or in intake air (used either as compressed air or for combustion).

\subsubsection{Article Exemption}

EPCRA Section 313 chemicals contained in articles that are processed or otherwise used are exempt from threshold determinations and release calculations. For an item to be exempt as part of an article, it must satisfy the following three criteria:

- be a manufactured item that is formed to a specific shape or design during manufacture,

- have end-use functions dependent in whole or in part on its shape or design during end use, and

- must not release an EPCRA Section 313 chemical under normal circumstances of processing or otherwise use of the item at the facility. Total releases from any item or like items qualifying as article exempt must be equal to or less than $0.5 \mathrm{lb}$ to remain exempt as articles (EPA 2006).

\subsubsection{De Minimis Exemption}

The de minimis exemption allows facilities to exempt certain minimal concentrations of EPCRA Section 313 chemicals contained in mixtures or other trade name products when making threshold determinations and release calculations. The de minimis concentrations are set by EPA at either $1 \%$ or $0.1 \%$, depending on whether the chemical is a suspected carcinogen or carcinogen.

EPA eliminated the de minimis exemption for the list of PBT chemicals. This means that facilities must include all amounts of PBTs in threshold determinations and release and other waste management calculations regardless of the concentration of the PBTs in mixtures or trade name products.

\subsection{Qualifiers}

In addition to exemptions, certain EPCRA Section 313 chemicals have qualifiers. Qualifiers indicate that these chemicals are subject to the reporting requirements only if manufactured, processed, or otherwise used in a specific form or when a certain activity is performed. Examples of qualifiers are shown in Table 2-1. 
Table 2-1 Examples of EPCRA Section 313 Chemical Qualifiers

\begin{tabular}{|c|c|c|}
\hline Chemical Name & $\begin{array}{l}\text { Chemical Abstract } \\
\text { Service (CAS) Number }\end{array}$ & Qualifier \\
\hline Aluminum & $7429-90-5$ & Only if it is a fume or dust form \\
\hline Hydrochloric Acid $(\mathrm{HCl})$ & $7647-01-0$ & Only if it is an aerosol form \\
\hline Isopropyl Alcohol & $67-63-0$ & $\begin{array}{l}\text { Only if it is being manufactured by the strong } \\
\text { acid process }\end{array}$ \\
\hline Sulfuric Acid & $7664-93-9$ & Only if it is an aerosol form \\
\hline Nitrate Compounds & $N A^{*}$ & Only when in aqueous solution \\
\hline Vanadium & $7440-62-2$ & Except when contained in an alloy \\
\hline
\end{tabular}

*NA $=$ not applicable

\subsection{ANALYSIS FOR THRESHOLD DETERMINATIONS}

There are several steps in determining when a chemical triggers reporting under EPCRA Section 313. When a chemical is manufactured, processed, or otherwise used in amounts greater than the threshold quantity, a Form R report and release calculations are required. Figure 3-1 presents a flowchart that shows the steps the Laboratory performs to determine which chemicals must be reported under EPCRA Section 313.

\subsection{Threshold Determinations for Chemical Use}

The Laboratory tracks chemicals brought onsite using a chemical inventory-tracking database called ChemLog. ChemLog captures the majority of procured chemicals and provides relevant data (e.g., chemical name, CAS number, quantity, etc.) to assist in threshold determinations. The underlying assumption used in the preliminary threshold determinations for reporting under EPCRA Section 313 is that chemicals are purchased and used in the same calendar year. If unusually large purchases are noted in this preliminary analysis, further investigation is done to determine if bulk chemicals were purchased and only a portion of them used in the calendar year.

\subsubsection{Inventory}

For calendar year 2006, a total of 49,363 records were added to ChemLog and evaluated; 22,458 were pure chemicals and 26,905 records were mixtures. Individual items with identifiable CAS numbers in ChemLog were considered pure chemicals. These items were matched by CAS number to the list of EPCRA Section 313 chemicals. The resulting records were summed in pounds for each pure chemical.

Individual items that did not have CAS numbers in ChemLog were considered mixtures. The exemptions discussed in Section 2.2 of this report were applied to the mixtures and each qualifying item was classified according to the applicable exemption. Material Safety Data Sheets (MSDSs) for the remaining mixtures purchased in quantities greater than $50 \mathrm{lb}$ were reviewed to determine the presence and amount of EPCRA Section 313 constituents. This was done to ensure that the chemicals with thresholds greater than $100 \mathrm{lb}$ would be identified. Listed chemicals with thresholds less than $100 \mathrm{lb}$ were examined individually, based on process knowledge and known potential sources. Each mixture that contained an 
EPCRA Section 313 chemical was further evaluated to determine the weight of each constituent. The totals for these amounts were then added to the quantities of pure EPCRA Section 313 chemicals.

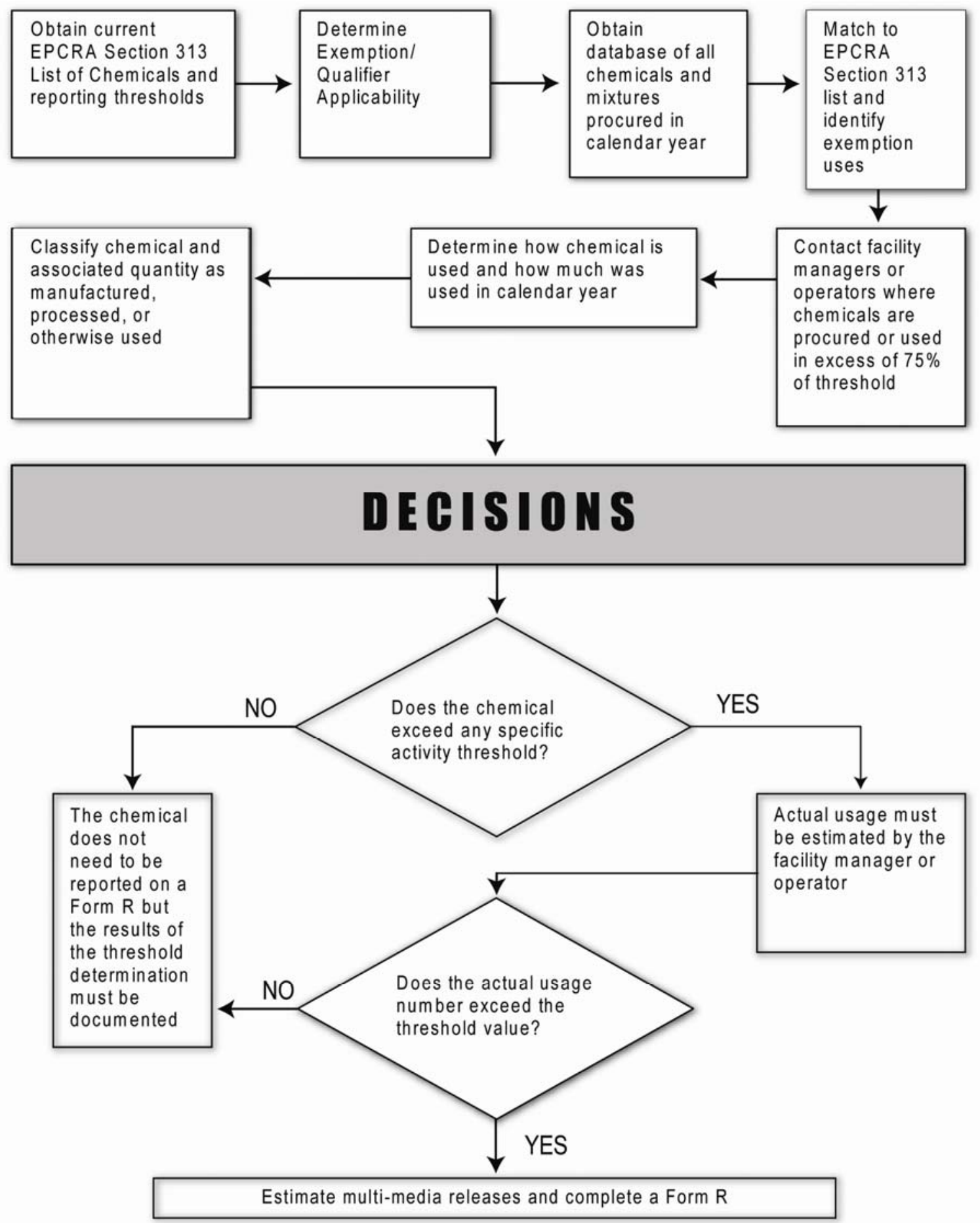

Figure 3-1 Flowchart process of analysis for EPCRA Section 313 reporting. 


\subsubsection{EPCRA Reporting Tool}

An automated search tool was developed using Microsoft Access to refine the data in ChemLog. The EPCRA reporting tool performs the following steps in the ChemLog data download:

- Identifies and labels exemptions through electronic text searches. The exemptions are from 40 CFR 372.38, Exemptions for Toxic Release Reporting. When a chemical is exempt, it is not considered when determining whether an applicable threshold has been met. Specifically, chemical containers were classified as follows:

* Maintenance - routine janitorial or facility grounds maintenance (e.g., cleaning supplies, paints, fertilizers, and pesticides);

* Maintaining Motor Vehicles (e.g., antifreeze, brake fluid);

* Personal Uses - non-process related items for employee personal use;

* De Minimus - the percent of a non-PBT Section 313 chemical in a mixture is less than $1 \%$ for a non-carcinogen or $0.1 \%$ for a carcinogen;

* Article - structural component exemption; and

* Laboratory Activities - if a toxic chemical is manufactured, processed, or used in a laboratory at a covered facility under the supervision of technically qualified individual.

- Identifies and labels EPCRA 313 compounds. There are 30 different chemical categories included on the EPCRA 313 list. Many of these categories do not have specific CAS numbers associated with them, except for polycyclic aromatic compounds (PACs) and dioxins. These two categories were evaluated in ChemLog as part of the pure chemical evaluation since they have searchable CAS numbers for compounds included in their categories. The other classes of compounds were searched in the 2006 ChemLog data set by using chemical-specific text searches in the chemical name field.

- Matches pure chemicals (chemical containers with an identifiable CAS number) with the list of EPCRA Section 313 chemicals by matching CAS numbers.

A few EPCRA Section 313 chemicals were selected for further analysis to determine if they were used in exempt activities. For 2006, the chemicals that were analyzed in more detail included

- $\mathrm{HCl}$,

- Sulfuric Acid,

- Nitric Acid,

- Nitrate Compounds,

- Mercury Compounds, and

- Lead Compounds.

\subsection{Threshold Determination Results}

\subsubsection{Procurement Totals}

The amounts of listed EPCRA Section 313 chemicals identified in the ChemLog, direct procurement, and 
other sources were all summed together to perform preliminary threshold determinations. The resulting totals for the top 10 listed EPCRA Section 313 chemicals are summarized below in Table 3-1.

Table 3-1 Top 10 EPCRA Section 313 Chemicals Procured in 2006

\begin{tabular}{lll}
\hline CAS No & Chemical Name & Total Procured (lb) \\
\hline $7664-93-9$ & Sulfuric Acid (liquid form) & 14,004 \\
$7647-01-0$ & Hydrochloric acid (liquid form) & 6,137 \\
$7697-37-2$ & Nitric Acid & 3,272 \\
$67-63-0$ & Isopropyl Alcohol & 2,439 \\
$75-09-2$ & Dichloromethane & 2,267 \\
NA & Cobalt Compounds & 2,257 \\
$75-45-6$ & Chlorodifluoromethane & 1,424 \\
$67-56-1$ & Methanol & 1,390 \\
NA & Manganese Compounds & 1,357 \\
$7429-90-5$ & Aluminum & 982 \\
\hline
\end{tabular}

A complete table of EPCRA Section 313 chemicals showing all contributing sources is provided in Appendix A. Chemicals that were procured in amounts greater than $75 \%$ of the applicable EPCRA Section 313 threshold were evaluated further and the analyses are summarized in Section 4 of this report.

\subsection{ADDITIONAL EVALUATION OF CERTAIN TOXIC CHEMICALS}

The toxic chemicals described below either are used in relatively high volumes at the Laboratory, have very low reporting thresholds, are of special interest, or have been reported in the past. Additional analyses were required to determine total usage of these chemicals. None of the chemicals presented in this section exceeded any of the applicable thresholds in 2006 and therefore no reporting was required.

\subsection{Mercury}

Mercury and mercury compounds are used in various places throughout the Laboratory. As part of the PBT rule, the threshold for EPCRA Section 313 reporting of mercury was reduced to $10 \mathrm{lb}$. In 2006, mercury was used in four areas at the Laboratory. Each is described below.

\subsubsection{Mercury Procurements}

A listing of all procurements in 2006 of mercury and mercury compounds was extracted from ChemLog. Line items containing a CAS number for mercury (7439-97-6) were included, as well as any line items containing the word "mercury" or the symbol " $\mathrm{Hg}$ " in the text description.

The total amount of mercury and mercury compounds in ChemLog for 2006 was $14.8 \mathrm{lb}$. The purchasers or users of the mercury and mercury compounds were contacted to determine the following:

- If the purchase was actually mercury or contained mercury or mercury compounds, 
- If a mixture or solution, what percent or parts per million (ppm) of mercury,

- If the mercury was used in a laboratory experiment setting, therefore it is subject to the laboratory exemption under EPCRA Section 313.

According to EPCRA Section 313 guidance documents, the laboratory exemption is applied to the quantity of a listed toxic chemical that is manufactured, processed, or otherwise used in a laboratory under the supervision of a technically qualified person. A total of $13.5 \mathrm{lb}$ of mercury was determined to actually be "mercury standard solutions" containing only ppm quantities of mercury. Further, these standard solutions are used in a laboratory exempt activity. The remaining $1.3 \mathrm{lb}$ of mercury from the ChemLog analysis was assumed to be otherwise used and applied to the 10 -lb threshold.

\subsubsection{Los Alamos Neutron Science Center Shutter System}

The largest use of mercury at the Laboratory is in the Los Alamos Neutron Science Center (LANSCE) shutter system. Reservoirs of mercury are used as shields on the neutron beam shutter system. When the beam is operated, pressurized helium is forced into the mercury reservoir, pushing the mercury up into a head space and allowing the neutron beam to pass through the shutter. LANSCE maintains 12 neutron beam shutter systems, each with a reservoir of mercury. The total amount of mercury in these reservoirs is approximately 12,000 lb. Each reservoir is a closed system and only opened occasionally when minor repairs or maintenance are completed.

During 2006, minor maintenance was performed on the mercury shutter system that included removing mercury from the system and then adding it back after the maintenance was completed. According to LANSCE personnel, the total amount of mercury displaced during maintenance in 2006 was approximately $3 \mathrm{lb}$ and this amount was added towards the 10-lb otherwise used threshold for mercury.

\subsubsection{Spallation Neutron Source Target Development Experiment}

The Spallation Neutron Source (SNS) Target Development Experiment began operations at the Laboratory in December 2001. The experiment also operated in 2002, 2005, and 2006. The experiment studies issues associated with using mercury as the target material for the SNS. The 2006 set up of the project involved shooting the neutron beam at a mercury-filled flowing loop. The loop is a closed system and it is not opened to the atmosphere.

In past years, the mercury added to the system has been considered laboratory exempt. No mercury was added in 2006.

\subsubsection{Fuel Combustion}

In 2006, the Laboratory generated mercury compound emissions from the following combustion sources: the Technical Area (TA) 21 steam plant, the asphalt plant, the TA-3 power plant, and from numerous small boilers. The mercury compound emissions from these sources totaled $0.23 \mathrm{lb}$ towards the manufactured threshold. Additionally, mercury is found in diesel fuel as an impurity. According to EPA guidance, the concentration of mercury in diesel fuel is $0.001 \mathrm{ppm}$ (EPA 2001a). LANL used approximately 29,546 gallons of diesel fuel in 2006 and this equates to $0.0002 \mathrm{lb}$ towards the otherwise used threshold. 


\subsubsection{Conclusion}

The total amount of mercury qualifying as otherwise used equals $4.3 \mathrm{lb}$, which is below the reporting threshold value of $10 \mathrm{lb}$. The total amount of mercury compounds manufactured was $0.23 \mathrm{lb}$, which is also below the reporting threshold of $10 \mathrm{lb}$. Therefore, it was determined that reporting of mercury under EPCRA Section 313 is not necessary for 2006. A summary of the 2006 mercury threshold determination is provided in Table 4-1.

Table 4-1 Summary of 2006 Mercury Threshold Determination

\begin{tabular}{|c|c|c|c|c|}
\hline Description & $\begin{array}{l}\text { Amount of } \\
\text { Mercury (lb) }\end{array}$ & Data Source & $\begin{array}{l}\text { EPCRA Section } 313 \\
\text { Activity Determination }\end{array}$ & $\begin{array}{l}\text { EPCRA Section } 313 \\
\text { Activity Threshold } \\
\text { (lb) }\end{array}$ \\
\hline $\begin{array}{l}\text { Purchasing of } \\
\text { Mercury Standards } \\
\text { and Instruments }\end{array}$ & 13.5 & $\begin{array}{l}\text { Procurement data and facility } \\
\text { personnel interviews }\end{array}$ & Laboratory Exempt & NA \\
\hline Other Procurement & 1.3 & Procurement Records & Otherwise Used & 10 \\
\hline $\begin{array}{l}\text { LANSCE Shutter } \\
\text { System }\end{array}$ & 3 & LANSCE Facility Records & & \\
\hline Fuel Combustion & 0.0002 & $\begin{array}{l}\text { Fuel Use Records and EPA } \\
\text { Guidance }\end{array}$ & & \\
\hline Fuel Combustion & 0.23 & $\begin{array}{l}\text { Fuel Use Records and EPA } \\
\text { AP-42 }\end{array}$ & Manufactured & 10 \\
\hline
\end{tabular}

\subsection{Sulfuric Acid}

EPCRA Section 313 reporting guidelines state that sulfuric acid must be reported only if it is in aerosol form, including mists, vapors, gas, fog, and other airborne forms of any particle size. This category would include acid aerosols generated in storage tanks and from fuel combustion. Large purchases of sulfuric acid are used in liquid form for demineralizer regeneration and for sample analysis at the Sanitary Waste Systems Consolidation (SWSC) Plant. In previous years, over 100,000 lb of sulfuric acid was used. In 2006 , only $12,450 \mathrm{lb}$ was used. The reason for the significant decrease is the installation of a reverse osmosis system in late 2003 that resulted in much lower use of caustics and acids. Because this sulfuric acid is used in liquid form, it is not subject to EPCRA Section 313 reporting.

Sulfuric acid aerosols are generated as a result of storage tank emissions, fuel combustion byproducts, and asphalt production. The total amount of sulfuric acid mist generated from these activities was $694.1 \mathrm{lb}$, less than the 25,000-1b manufacture threshold and, therefore, not reportable under EPCRA. Based on EPA guidance for fuel oil combustion, it is assumed that all sulfur trioxide $\left(\mathrm{SO}_{3}\right)$ emissions are in the form of sulfuric acid (EPA 1998a). For natural gas combustion, it is conservatively assumed that all sulfur oxides emissions are in the form of sulfuric acid mist because separate $\mathrm{SO}_{3}$ emission factors are not available.

In 2006, numerous small purchases totaling 1,555 lb of sulfuric acid were procured at the Laboratory. These numerous small purchases of sulfuric acid captured in ChemLog are assumed to be in aerosol form since the specific usage is unknown. Total purchases do not exceed the otherwise use reporting threshold. A summary of the threshold determinations for sulfuric acid is provided in Table 4-2. 
Table 4-2 Sulfuric Acid Threshold Determination for 2006

\begin{tabular}{|c|c|c|c|c|}
\hline Description & $\begin{array}{l}\text { Amount of } \\
\text { Sulfuric Acid (lb) }\end{array}$ & Data Source & $\begin{array}{c}\text { EPCRA Section } 313 \\
\text { Activity } \\
\text { Determination }\end{array}$ & $\begin{array}{c}\text { EPCRA Section } 313 \\
\text { Activity Threshold } \\
\text { (lb) }\end{array}$ \\
\hline $\begin{array}{l}\text { Demineralizer } \\
\text { Regeneration }\end{array}$ & 12,450 & Site Support Contractor Logs & $\begin{array}{l}\text { Not in aerosol form } \\
\text { and not subject to } \\
\text { EPCRA Section } 313\end{array}$ & NA \\
\hline $\begin{array}{l}\text { Water Analysis at } \\
\text { the SWSC Plant }\end{array}$ & 55.4 & Site Support Contractor Logs & & \\
\hline $\begin{array}{l}\text { Procurement Not } \\
\text { Evaluated }\end{array}$ & 1,555 & ChemLog & Otherwise used* & 10,000 \\
\hline $\begin{array}{l}\text { Storage Tank Air } \\
\text { Emissions }\end{array}$ & 0.003 & EPA, Tanks 4.0 Software & Manufactured & 25,000 \\
\hline $\begin{array}{l}\text { Fuel Combustion } \\
\text { Byproducts }\end{array}$ & 684.1 & AP-42 and fuel use records & & \\
\hline $\begin{array}{l}\text { Asphalt Plant } \\
\text { Production }\end{array}$ & 10 & AP-42 and facility records & & \\
\hline
\end{tabular}

\subsection{Hydrochloric Acid}

$\mathrm{HCl}$ is purchased for numerous processes and is also generated as a combustion byproduct. The total amount of $\mathrm{HCl}$ procured in 2006 was $6,137 \mathrm{lb}$. This includes $\mathrm{HCl}$ from pure chemicals and mixtures in ChemLog. Facility and Waste Operations purchased approximately 4,070 lb of aqueous $\mathrm{HCl}$ in 2006. This $\mathrm{HCl}$ was used for heat exchanger scale cleaning and for cleaning of electrodialysis reversal membranes. In its aqueous form, it is not subject to EPCRA Section 313 due to the qualifier of only "acid aerosols" counting towards the threshold (EPA 1999). The additional amount of $\mathrm{HCl}$ from ChemLog was $2,067 \mathrm{lb}$, including aqueous and aerosol forms of $\mathrm{HCl}$. To be conservative, the entire amount was assumed to be in an aerosol form and was evaluated against the 10,000-lb otherwise use threshold, which it did not exceed. Therefore, it was not necessary to report $\mathrm{HCl}$ in 2006.

\subsection{Polycyclic Aromatic Compounds}

PACs are a chemical category included on the EPCRA Section 313 list as part of the PBT rule. The threshold for reporting PACs is $100 \mathrm{lb}$. Benzo(g,h,i)perylene is a PAC that has its own separate threshold. The threshold for benzo(g,h,i)perylene is $10 \mathrm{lb}$.

According to EPA's "EPCRA Section 313 Guidance for Reporting Toxic Chemicals: Polycyclic Aromatic Compounds Category" (EPA 2001b), fuel oil and paving asphalt contain PACs. In addition, PACs may be generated from the combustion of natural gas and fuel oil and the manufacture of asphalt. Each of these sources of PACs was evaluated and is described below. 


\subsubsection{Procurement of PACs}

Under EPCRA Section 313, the PAC category includes 21 specific chemicals and an additional 51 chemical mixtures that are listed as potentially containing PACs. A search of the ChemLog data set was done using CAS numbers for the 21 chemicals and text searches for the 51 chemical mixtures. No matches were identified and the total PACs from the ChemLog analysis for 2006 is zero.

\subsubsection{PACs from Asphalt Production}

In 2006, the Laboratory produced approximately 2,008 tons of asphalt and used 23,736 gallons of asphalt tar. A review of project management records for 2006 identified projects that involved the purchase of asphalt from outside contractors. Work tickets and project management records were reviewed to identify asphalt jobs that qualify as routine facility maintenance and are exempt under EPCRA Section 313. Routine facility maintenance includes patching of potholes, repair of roads and parking lots, and resurfacing of existing parking lots. After reviewing these records, only two projects were identified that did not fall under the facility maintenance exemption.

According to EPA guidance, asphalt tar may contain as high as $178 \mathrm{ppm}$ of PACs (EPA 2001b). However, Chevron-Texaco, the supplier of the asphalt tar, provided information specific to their product (Chevron-Texaco 2001). The information indicated the PACs concentration in the asphalt tar was significantly lower than that listed as a default value in the EPA's PACs guidance. These manufacturersupplied values were used in the Laboratory calculation of PACs. The concentration of PACs in the asphalt tar is 8 ppm (versus EPA default value of $178 \mathrm{ppm}$ ).

Using the 8-ppm concentration, the total amount of PACs otherwise used at the Laboratory in all asphalt work in 2006 is $23.0 \mathrm{lb}$. The concentration of benzo(g,h,i)perylene in asphalt, from EPA's Guidance on PBTs, is $1.2 \mathrm{ppm}$ (EPA 2001c). This figure gives $3.45 \mathrm{lb}$ of benzo(g,h,i)perylene reportable towards its 10 -lb otherwise use threshold.

\subsubsection{PACs from Fuel Oil Combustion}

Approximately 29,546 gallons of diesel fuel was used in 2006 in the Laboratory's power plant and miscellaneous boilers and generators. According to EPA guidance, fuel oil may contain 10 ppm of PACs (EPA 2001b). However, data provided by Chevron-Texaco indicate diesel may contain 22 ppm of PACs (Chevron-Texaco 2001). The $22 \mathrm{ppm}$ was used in these calculations. This equates to $4.62 \mathrm{lb}$ of PACs that apply to the otherwise use threshold. The concentration for benzo(g,h,i)perylene was found to be 0.05 ppm according to EPA guidance (EPA 2001c). Data provided by Chevron-Texaco indicated concentrations of $9 \mathrm{ppm}$. The $9 \mathrm{ppm}$ was used in these calculations and results in $1.89 \mathrm{lb}$ of this particular PAC, applicable to the 10 -lb otherwise use threshold.

In addition, combustion of fuel oil generates emissions of PACs that apply to the manufacture threshold. Using AP-42 emission factors (EPA 1998a), these amounts were calculated to be $4.9 \times 10^{-4} \mathrm{lb}$ for total PACs and $6.7 \times 10^{-5} \mathrm{lb}$ for benzo(g,h,i)perylene. 


\subsubsection{PACs from Natural Gas}

Approximately 1,129.2 million standard cubic feet of natural gas was burned at the Laboratory facilities in 2006. Using AP-42 emission factors (EPA 1998b) and fuel records, approximately $0.018 \mathrm{lb}$ of PACs was produced from natural gas combustion, which is applied to the manufacture threshold. Approximately $0.0014 \mathrm{lb}$ of benzo(g,h,i)perylene applies toward the 10-lb manufacture threshold. Due to the absence of information regarding total PAC and benzo(g,h,i)perylene concentrations in natural gas, it was assumed these substances are negligible in natural gas before combustion.

\subsubsection{Summary of PACs}

The largest source of PACs at the Laboratory in 2006 was asphalt use. The total amount used from all sources is $27.6 \mathrm{lb}$. The total amount manufactured from combustion of fuel oil and natural gas is $0.018 \mathrm{lb}$. Both threshold quantities for otherwise use and manufacture were below the 100-lb threshold, therefore, it was determined that reporting of PACs under EPCRA Section 313 was not necessary.

Benzo(g,h,i)perylene concentrations in asphalt tar and diesel fuel totaled $5.3 \mathrm{lb}$ towards the otherwise used threshold. Combustion processes accounted for $0.0015 \mathrm{lb}$, which is considered to be manufactured. These values are well below the reporting threshold of $10 \mathrm{lb}$. Therefore, benzo(g,h,i)perylene reporting was not necessary under EPCRA Section 313 in 2006. Table 4-3 summarizes the PACs and benzo $(\mathrm{g}, \mathrm{h}, \mathrm{i})$ perylene threshold determinations.

Table 4-3 LANL 2006 Threshold Determinations for PACs and Benzo(g,h,i)perylene

\begin{tabular}{llllll}
\hline $\begin{array}{c}\text { EPCRA Chemical/ } \\
\text { Compound }\end{array}$ & \multicolumn{1}{c}{ Process or Material } & Amount (lbs) & Total (lbs) & $\begin{array}{c}\text { EPCRA Section } \\
\text { 313 Activity } \\
\text { Determination }\end{array}$ & $\begin{array}{c}\text { EPCRA Activity } \\
\text { Threshold (lbs) }\end{array}$ \\
\hline Total PACs & Impurity in natural gas & 0.0 & 27.62 & Otherwise Used & 100 \\
& Asphalt tar & 23.0 & & & \\
& Impurity in fuel oil & 4.62 & & & \\
& Natural gas combustion & 0.018 & 0.018 & Manufactured & 100 \\
& Fuel oil combustion & $4.88 \times 10^{-4}$ & & & \\
\hline Benzo(g,h,i)perylene & Impurity in natural gas & 0.0 & 5.34 & & \\
& Asphalt tar & 3.45 & & Otherwise Used & 10 \\
& Impurity in fuel oil & 1.89 & & & \\
& Natural gas combustion & 0.0014 & 0.0015 & Manufactured & \\
& Fuel oil combustion & $6.7 \times 10^{-5}$ & & & \\
\hline
\end{tabular}




\subsection{Dioxins}

Dioxins are a group of PBTs formed during combustion processes. The EPCRA Section 313 reporting threshold for the dioxins category is 0.1 gram manufactured, processed, or otherwise used. This limit applies to toxic-equivalent compounds, a category of dioxins consisting of 17 specific dioxin and dioxinlike compounds. These "compounds with chlorine substitution in the 2,3,7,8-positions on the molecule are reportable under the EPCRA Section 313 dioxin and dioxin-like compounds category" (EPA 2000a).

Activities at the Laboratory that were evaluated for dioxins include explosives activities and fuel combustion. Each is described below.

\subsubsection{Explosives Activities}

Dioxins are formed by burning chlorine-based chemical compounds with hydrocarbons producing an unintentional byproduct in many industrial processes involving chlorine. One potential source of dioxin formation at the Laboratory is open burn/open detonation (OB/OD) of high explosives (HE). This is because many binders and plasticizers found in HE materials have chlorine in their chemical make-up. Therefore, analysis of HE materials and associated binders/plasticizers was performed to estimate dioxin emissions.

Information on the various HE materials, such as explosive type, explosive name, composition, and chemical formula, was obtained from Laboratory personnel and textbooks. Some HE materials contain binders and plasticizers. These binders and plasticizers were evaluated and screened for those that contained chlorine. For those chlorine-containing binders/plasticizers, the weight percent chlorine in each was determined and the HE materials having chlorine-containing binders were further evaluated. Knowing the weight percent binder/plasticizer in these explosives and the weight percent chlorine in each binder, the amount of binder and amount of chlorine in each HE material containing chlorine was determined. Due to the unique nature of these materials, no specific dioxin emission factors are available. Therefore, a dioxin emission factor for burning of polyvinyl chloride in accidental fires was used to estimate dioxin emissions from burning of the chlorine-containing materials (American Society of Mechanical Engineers 1995). An emission factor of $4 \mu \mathrm{g}$ dioxin emitted per ton of material burned was used.

Based on available information, estimated emissions from dioxins formed by OB/OD of HE materials totaled $4.04 \times 10^{-6}$ grams per year. Furthermore, burning of HE materials at the LANL Burn Ground was evaluated separately for dioxin formation. A more conservative approach was used to estimate dioxin emissions from burning of HE materials. The assumption was made that all HE-contaminated waste could potentially result in dioxin formation. Emission factors developed by EPA for the burning of ammonium perchlorate propellant were used (EPA 1998c). Based on estimating emissions from all waste materials burned, dioxin emissions were $3.04 \times 10^{-5}$ grams per year. 


\subsubsection{Fuel Combustion}

The Laboratory burns natural gas and diesel fuel in numerous boilers, heaters, and generators. No emission factors for dioxins were found for natural gas combustion. However, EPA EPCRA guidance for dioxins provides an emission factor of 3,178.6 picograms per liter of diesel fuel burned (EPA 2000a). The Laboratory burned a total of 29,546 gallons (111,832 liters) of diesel fuel in 2006. Multiplying by the dioxin emission factor, a total of $3.55 \times 10^{8}$ picograms (0.00036 grams) of dioxin was formed due to fuel combustion.

The total calculated dioxin emissions in 2006 are below the 0.1 -gram threshold and, therefore, reporting under EPCRA Section 313 is not required. Table 4-4 summarizes the amount of dioxins formed from all sources characterized for 2006.

Table 4-4 Dioxin Threshold Determination for 2006

\begin{tabular}{llll}
\hline \multicolumn{1}{c}{ Description } & \multicolumn{1}{c}{$\begin{array}{c}\text { Amount of Dioxin Formed } \\
\text { (grams) }\end{array}$} & $\begin{array}{c}\text { EPCRA Section 313 } \\
\text { Activity Determination }\end{array}$ & $\begin{array}{c}\text { EPCRA Section 313 } \\
\text { Threshold (grams) }\end{array}$ \\
\hline HE Expended & $4.04 \times 10^{-6}$ & Manufactured & 0.1 \\
HE Burned & $3.04 \times 10^{-5}$ & Manufactured & 0.1 \\
Fuel Combustion & $3.6 \times 10^{-4}$ & Manufactured & 0.1 \\
Total Dioxin Formed & 0.0004 & & 0.1 \\
\hline
\end{tabular}

\subsection{Nitrate Compounds}

According to EPA's EPCRA Section 313 Guidance "List of Toxic Chemicals within the Water Dissociable Nitrate Compounds Category and Guidance for Reporting" (EPA 2000b), nitrate compounds may be manufactured through the elemental neutralization of nitric acid and through the collection and treatment of sanitary wastewater. These sources of nitrate compounds are applicable to the Laboratory and are discussed in this section. The reporting thresholds for nitrate compounds are 25,000 lb for manufacture/import or process and 10,000 lb for otherwise used. Only the manufacture and otherwise used thresholds apply to the Laboratory for 2006 EPCRA reporting.

The above listed guidance provides a list of approximately 50 nitrate compounds that are included as water dissociable nitrate compounds. Although this list is not exhaustive, it provides commonly identified nitrate compounds. Only those compounds in aqueous solution ( $>50 \%$ water) are required to be reported. Also, a de minimis concentration of $1 \%$ is applied to all nitrate compounds found in mixtures. When determining the reporting threshold for nitrate compounds, the entire nitrate compound is included (both the nitrate and its counter ion) toward determining the threshold. If the threshold is exceeded, only the nitrate portion of the compound is reported.

For the manufacture threshold, the sources reviewed included waste nitric acid treated at the Radioactive Liquid Waste Treatment Facility (RLWTF), which uses sodium hydroxide in an elementary neutralization process. The other source was the SWSC Plant. The nitrate compounds that were applied to the otherwise used threshold included nitrate compounds purchased or used during 2006. Other nitrate compounds evaluated were determined to be non-aqueous and were not required to be included in threshold determinations. 


\subsubsection{Chemical Review}

A query of ChemLog was performed to determine the amount of chemicals applied to the otherwise used threshold. Approximately $92 \mathrm{lb}$ of nitrate compounds were purchased in 2006. As a conservative assumption it is assumed these are in aqueous form and apply to the otherwise used threshold.

\subsubsection{Sanitary Wastewater}

The SWSC Plant collects sanitary waste (sewage and other allowable discharges) from several LANL facilities and treats the waste in a standard primary (physical), secondary (biological) treatment system. Information was collected from the SWSC Plant on nitrate influent concentration and total flow rate for the purpose of EPCRA Section 313 threshold determination. The information provided indicated an average nitrate concentration of the influent of 1.11 milligrams per liter and total flow into the system during 2006 was 77,050,000 gallons.

Using the flow rate given by the plant, the total annual average amount of nitrate compound (as sodium nitrate) was calculated. At the average nitrate concentration of 1.11 milligrams per liter, and adjusting the weight to include the sodium ion, the total sodium nitrate processed as an impurity was $978 \mathrm{lb}$ in 2006 .

The information provided by the SWSC Plant also included the amount and the nitrate concentration of the effluent treated water. The total amount of treated water out of the SWSC Plant in 2006 was 103,245,000 gallons. The average nitrate concentration was $3.9 \mathrm{mg} / \mathrm{L}$. This calculates to a total of 4,602 $\mathrm{lb}$ of nitrates (as sodium nitrate) manufactured.

\subsubsection{Nitric Acid Neutralization}

Typically, waste nitric acid from the mixed oxide (MOx) process and from the Nitric Acid Recycling System (NARS), both located at the Plutonium Facility, is sent to the RLWTF for treatment. The RLWTF provided information on the volume and concentration of acid received from the plutonium facility in 2006. The quantity of nitric acid received in 2006 was approximately 1,270 liters of 4-molar nitric acid (approximately 22\%).

The amount of nitrate compounds formed due to nitric acid treated during 2006 by the RLWTF was calculated using the formula found in the EPA "Nitrate Compound Guidance" (EPA 2000b). The total amount of liquid collected was multiplied by the percent nitric acid. The total amount of nitric acid neutralized was $694 \mathrm{lb}$. The formula determines how many kilomoles of nitric acid were neutralized, which is equal to the kilomoles of sodium nitrate generated. The nitrate compound (sodium nitrate) generated from the neutralization process equaled $936 \mathrm{lb}$.

\subsubsection{Summary}

Nitrate compounds that apply to the otherwise used reporting threshold of 10,000 lb include the chemicals found in ChemLog. A total of $92 \mathrm{lb}$ of nitrate compounds were purchased and assumed to be in aqueous form. This is well below the 10,000-lb EPCRA Section 313 threshold. 
Nitrate compounds that apply to the manufacture reporting threshold of 25,000 lb include those identified in the sanitary wastewater at the SWSC Plant and the nitrate compounds identified during the elementary neutralization of nitric acid at the RLWTF. These two activities totaled 5,538 lb of nitrate compounds manufactured. The amount of nitrate compounds processed as an impurity from these two activities was $1,672 \mathrm{lb}$. It was determined that no thresholds for nitrate compounds were exceeded in 2006 . Table 4-5 provides a summary of nitrate compounds at LANL in 2006.

Table 4-5 Summary of Nitrate Compounds at LANL in 2006

\begin{tabular}{llll}
\hline Nitrate Compounds & Amount (lb) & $\begin{array}{l}\text { EPCRA Section 313 Activity } \\
\text { Determination }\end{array}$ & $\begin{array}{l}\text { EPCRA Section } 313 \\
\text { Threshold (lb) }\end{array}$ \\
\hline $\begin{array}{l}\text { Purchased in ChemLog (assumed in } \\
\text { aqueous form and otherwise used) }\end{array}$ & 92 & Otherwise Used & $10,000 \mathrm{lb}$ \\
$\begin{array}{l}\text { Processed at SWSC Plant } \\
\text { Processed at RLWTF }\end{array}$ & 978 & Processed & $25,000 \mathrm{lb}$ \\
Manufactured at SWSC Plant & 694 & & \\
Manufactured at RLWTF & 1,672 & Manufactured & $25,000 \mathrm{lb}$ \\
& 4,602 & & \\
& 936 & & \\
\hline
\end{tabular}

\subsection{Nitric Acid}

In general, nitric acid is used in high volume at the Laboratory every year. The main uses are research and development activities, sample preparation, plutonium processing, and the Laboratory's bioassay program. Small amounts of nitric acid are used for cleaning glassware. The total amount of nitric acid used at LANL in 2006 did not exceed the EPCRA Section 313 otherwise use threshold of 10,000 lb.

\subsubsection{Procurement}

Nitric acid procured and used at the Laboratory in 2006 was evaluated to determine the amounts that could be applied to the EPCRA Section 313 laboratory exemption. According to EPCRA Section 313 guidance documents, the laboratory exemption is applied to the quantity of a listed toxic chemical that is manufactured, processed, or otherwise used in a laboratory under the supervision of technically qualified personnel. However, quantities of a listed toxic chemical used for cleaning glassware do not qualify for this exemption.

In 2006, a total of 3,279 $\mathrm{lb}$ of nitric acid was procured at the Laboratory, based on queries of the ChemLog system. Some of the purchase records indicate the nitric acid is actually $69 \%$ to $71 \%$ nitric acid in an aqueous solution, or more dilute solutions. Numerous phone calls were made to determine the percent nitric acid solution purchased where it was not specified. In almost all cases, the nitric acid is purchased as "lab grade," which is $65 \%$ to $70 \%$ nitric acid in water. The concentration of the nitric acid purchases was taken into account and the resulting amount of pure nitric acid purchased was calculated to be $2,434 \mathrm{lb}$.

This is a continuing downward trend in purchasing based on the amounts procured in the previous years. 
Nuclear Materials Technology (NMT) Division is the largest user of nitric acid and they had very limited operations due to facility and maintenance upgrades. Historically, NMT Division purchases nitric acid in bulk and stores it in a nitric acid storage tank. However, in 2006 no additional nitric acid was purchased for the tank, and very little nitric acid was used from the tank inventory.

Other large users of nitric acid were contacted to determine how the nitric acid was used. Relatively large quantities of nitric acid continue to be used for the bioassay program (monitoring employees for radioactive elements). Numerous other users within the Chemistry Division were contacted and verified the use of nitric acid for sample preparation and analysis. In 2006, this use totaled 1,942 lb. Information was also obtained on the approximate amount of nitric acid used for cleaning laboratory glassware, which is not considered a laboratory exempt activity. The total amount calculated to be used for cleaning glassware was $128 \mathrm{lb}$. Therefore, the total amount of nitric acid used in laboratory exempt activities was $1,814 \mathrm{lb}(1942-128)$.

The quantity of nitric acid used by personnel that were not contacted (except for NMT Division, which is described below), or that described their use of nitric acid as process related (including cleaning glassware) totaled $619 \mathrm{lb}$. As a conservative assumption, this amount is assumed to be otherwise used.

\subsubsection{NMT Plutonium Processing}

The plutonium processing facility provided information on the amount of nitric acid used in 2006. Both the MOx fuels project and the ATLAS project were inactive until very late in the year. The facility provided information that 8,000 liters of nitric acid were used in 2006. Approximately 7,000 liters came from the holding tanks off the NARS and is a 7-molar (40\%) solution of nitric acid in water. The remaining 1,000 liters is a stronger concentration, approximately 14- to15-molar (70\%) solution of nitric acid in water. From MSDS review, the density for $40 \%$ nitric acid is $9.6 \mathrm{lb}$ per gallon and a $70 \%$ nitric acid solution is $11.5 \mathrm{lb}$ per gallon.

$(7,000 \mathrm{~L} \times 0.4) /(3.785 \mathrm{~L} / \mathrm{gal}) \times(9.6 \mathrm{lb} / \mathrm{gal})+$

$(1,000 \mathrm{~L} \times 0.7) /(3.785 \mathrm{~L} / \mathrm{gal}) \times(11.5 \mathrm{lb} / \mathrm{gal})=9,228 \mathrm{lb}$ nitric acid

\subsubsection{Summary}

Nitric acid use in 2006 is below the EPCRA Section 313 10,000-lb otherwise used threshold and, therefore, is not reportable. Table 4-6 provides a summary of nitric acid use at LANL in 2006. 
Table 4-6

Summary of Nitric Acid Use at LANL in 2006

\begin{tabular}{llll}
\hline \multicolumn{1}{c}{ Nitric Acid Use } & \multicolumn{1}{c}{ Amount (lb) } & \multicolumn{1}{c}{ EPCRA Status } & \multicolumn{1}{c}{ Threshold for Reporting } \\
\hline Laboratory Use & 1,814 & Lab Exempt & Exempt \\
Otherwise Use & & Otherwise Use & $10,000 \mathrm{lbs}$ \\
Non-lab, or unknown use & 619 & & \\
Plutonium processing & 9,228 & & \\
Total Otherwise Use & $\mathbf{9 , 8 4 7}$ & & \\
\hline
\end{tabular}

\subsection{LEAD AND FORM R REPORTING}

\subsection{Threshold Determination}

Lead and lead compounds are used in various processes throughout the Laboratory. In January 2001, EPA promulgated a rule lowering the threshold for EPCRA Section 313 reporting of lead and lead compounds to $100 \mathrm{lb}$, effective for reporting year 2001. In 2006, lead and lead compounds were used or manufactured in the following operations at the Laboratory.

\subsubsection{Lead Procurements}

A listing of all procurements in 2006 of lead and lead compounds was extracted from ChemLog. Line items containing a CAS number for lead (7439-92-1) were included, as well as any line items containing the word "lead" or the symbol " $\mathrm{Pb}$ " in the text description.

The total amount of lead and lead compounds added to ChemLog for 2006 was 1,093.5 lb. However, over $1,000 \mathrm{lb}$ of this was lead-acid batteries, which are considered article exempt. According to EPCRA Section 313 guidance documents, the laboratory exemption is applied to the quantity of a listed toxic chemical that is manufactured, processed, or otherwise used in a laboratory under the supervision of a technically qualified person. Line items in ChemLog that were clearly described as lead standards were assumed to be used in a laboratory setting and exempt from reporting. This accounted for $1.76 \mathrm{lb}$. Also, the EPCRA Section 313 guidance states that the Article Exemption is for chemicals present in articles formed to a specific shape and do not release a Section 313 chemical under normal conditions during use. In 2006, the article exemption applied to 39 lead-acid batteries that accounted for 1,076.4 lb of lead. The total amount of lead and lead compounds from procurements applied to the otherwise used threshold is $15.35 \mathrm{lb}$.

\subsubsection{Lead Use at the Firing Range}

Lead is a component in various types of ammunition. The Laboratory maintains an onsite firing range for training security personnel. The firing range keeps detailed records of the amount and type of munitions expended. The U.S. Department of Defense developed software for estimating usage and releases of EPCRA Section 313 chemicals from various munitions activities (EPA www.epa.gov/tri). The TRI-Data Delivery System (TRI-DDS) software was used to calculate the amounts of toxic chemicals associated with munitions used at LANL for comparison with EPCRA Section 313 reporting thresholds and calculation of environmental releases. Some ammunition used at LANL was not represented in TRI-DDS. 
In these cases, the manufacturer was contacted to obtain specific information on lead for that ammunition.

The total lead released to the environment at the firing range was slightly higher in 2006 as compared to previous years. Using the TRI-DDS software, it was determined that $8,878.2 \mathrm{lb}$ of lead and $19.5 \mathrm{lb}$ of lead compounds were used.

The 2006 amount of lead released to land (non-air) was 8,878 lb. This amount equals the amount otherwise used. Lead compounds are also manufactured through the firing of ammunition. These lead compounds were calculated using the TRI-DDS software. It was determined that $10.9 \mathrm{lb}$ of lead compounds were manufactured, with $10.0 \mathrm{lb}$ released to the air.

\subsubsection{Lead from Fuel Combustion}

In 2006, the Laboratory emitted lead compound emissions from the following combustion sources: the TA-21 steam plant, the TA-3 power plant, and from numerous small boilers, which used approximately 1,129.2 million standard cubic feet (MMscf) of natural gas. The AP-42 emission factor for lead compounds from natural gas combustion in both large and small boilers is $0.0005 \mathrm{lb} / \mathrm{MMscf}$. The lead compound emissions from these sources totaled $0.56 \mathrm{lb}$ towards the manufactured threshold. The Laboratory also burned an estimated 29,546 gallons of diesel fuel in boilers, heaters, and diesel-fired generators. The AP-42 emission factor for diesel fuel combustion is $0.00123 \mathrm{lb}$ per 1,000 gallons; this equates to $0.036 \mathrm{lb}$ of lead compound manufactured.

Additionally, lead is found in fuel oil and natural gas as an impurity. According to EPA guidance (EPA 2001d), the concentration of lead in No. 2 fuel oil is $0.5 \mathrm{ppm}$ and in natural gas 0.05 milligrams per cubic meter.

The fuel oil contained $0.11 \mathrm{lb}$ of lead and 1,129.2 MMscf of natural gas contained $3.49 \mathrm{lb}$ of lead, which are added to the otherwise used threshold.

\subsubsection{Lead from Asphalt Plant}

A total of 2,008 tons of asphalt were produced in 2006. The AP-42 emission factor for lead from hot mix asphalt plants is $8.90 \mathrm{E}-7 \mathrm{lb}$ per ton asphalt (EPA 2004). This equates to $0.0018 \mathrm{lb}$ of lead compounds manufactured.

\subsubsection{Lead Use at LANSCE}

The Laboratory continues to maintain an inventory of lead shielding and lead bricks at LANSCE and other areas of the Laboratory. In recent years, the Laboratory has attempted to reduce the inventory by sending some of the lead offsite to be reused. According to EPA's web-based TRI advanced training course presented by SAIC on May 10, 2005, "the recovery of a listed Section 313 chemical for further distribution in commerce or commercial use is "processing' of that chemical." Also, materials sent offsite for direct "reuse" are not reported on Form R, but material sent offsite for recycling are reported on Form R in Part II, Section 6.2. EPA considers the direct recirculation of a toxic chemical within a process or between processes without any intervening reclamation or recovery to be "reuse." Furthermore, "reclamation or recovery" does not include simple phase changing of the toxic chemical before further reuse (e.g., simple remelting of scrap metal). 
The process for shipping scrap metal for recycle has been centralized at the Metals Recycle Facility (MRF), part of LANL's Salvage process. The MRF stages the metal and coordinates pick-up by a metal recycling company. The MRF estimates that $63,140 \mathrm{lb}$ of lead were shipped offsite for recycle and resale in 2006 .

The lead sent to the metal recycling company is considered processed because it is distributed for commercial use. The metal recycling company repackages the lead and then sends it to a lead smelter. Because the lead is simply remelted, it is defined as "reused." Therefore, it will not be reported on the Form R in Part II, Section 6.2.

Solid Waste Operations was contacted for information on the amount of lead sent to other DOE facilities as part of the DOE Intercomplex Lead Reuse program. This lead is also considered processed and it is not reported on Form R because it will be "reused." This program is no longer operating and, therefore, no lead was shipped to other DOE facilities in 2006.

In 2004, LANSCE received 40,000 lb of lead from France for the Lead Cooling Project. This lead is still onsite at LANL and is still being used for experiments. However, it was counted towards threshold reporting for 2004 and so will not be counted in the thresholds for 2006 as this would result in double counting. This lead will be returned to France when the project ends.

\subsubsection{Other LANL Operations Using Lead and Lead Compounds}

In previous years, the Laboratory has conducted operations to decontaminate lead shielding and lead melting and cutting operations to form new shielding. Onsite processing of both of these activities was suspended in 2000. The Laboratory installed a new lead-bismuth test loop at LANSCE in 2001. The test loop contains approximately 8,000 lbs of lead bismuth. There were no additions of lead bismuth in 2006.

\subsubsection{Conclusion}

The largest source of lead use at the Laboratory is from the lead recycling, which accounted for 63,140 lbs of lead towards the processed threshold. In 2006, the firing range accounted for $8,878 \mathrm{lbs}$ of lead towards the otherwise used threshold. Table 5-1 summarizes the threshold determination for lead and lead compounds for 2006. Based on these operations, it was determined that lead was processed and used over threshold quantities. However, lead compounds did not exceed the reporting threshold. Therefore, for 2006 reporting, a Form R will be completed just for lead. 
Table 5-1 Summary of Threshold Determination for Lead and Lead Compounds for 2006

\begin{tabular}{|c|c|c|c|}
\hline Activity & Lead "Use"(Ibs) & Lead Compound "Use"(Ibs) & Comments \\
\hline Firing Range & 8,878 & 19.5 & Otherwise Used \\
\hline Firing Range & 0 & 10.0 & Manufactured \\
\hline \multirow{3}{*}{$\begin{array}{l}\text { Lead Purchases } \\
\text { (ChemLog) }\end{array}$} & \multirow[t]{3}{*}{0} & \multirow[t]{3}{*}{15.35} & Otherwise Used \\
\hline & & & $\begin{array}{l}1,093.51 \mathrm{lbs} \\
\text { purchased, }\end{array}$ \\
\hline & & & $\begin{array}{l}\text { 1,078.16 lbs Article } \\
\text { exempt or Lab Exempt }\end{array}$ \\
\hline $\begin{array}{l}\text { Lead } \\
\text { Recycle/Resale } \\
\text { (sold to Ace Metals) }\end{array}$ & 63,140 & 0 & $\begin{array}{l}\text { Processed, all of it is } \\
\text { "reused" and not } \\
\text { reported on the Form } \\
\text { Rs }\end{array}$ \\
\hline $\begin{array}{l}\text { Lead Re-Use from } \\
\text { LANSCE (DOE } \\
\text { inter-complex } \\
\text { transfer) }\end{array}$ & 0 & 0 & Processed for re-use \\
\hline Fuel Combustion & 0 & 0.59 & $\begin{array}{l}\text { Manufactured (sum of } \\
\text { natural gas, diesel, and } \\
\text { asphalt) }\end{array}$ \\
\hline Fuel Combustion & 3.49 & 0 & Otherwise Used \\
\hline \multirow[t]{2}{*}{$\begin{array}{l}\text { TOTAL Nonexempt } \\
\text { Use }\end{array}$} & Otherwise Used - 8,881 & Otherwise Used - 34 & \multirow{2}{*}{$\begin{array}{l}\text { Reporting Thresholds = } \\
100 \mathrm{lbs}\end{array}$} \\
\hline & Processed - 63,140 & $\begin{array}{l}\text { Processed - } 0 \\
\text { Manufactured - } 10.6\end{array}$ & \\
\hline
\end{tabular}

\subsection{Environmental Releases and Offsite Disposal}

\subsubsection{Air Emissions}

Although most of the air emissions are in the form of lead compounds, the Laboratory has chosen to report the entire weight of the lead compound air emissions on the Form $\mathrm{R}$ for lead.

\subsubsection{Firing Range}

The Laboratory operates a firing range on site for security personnel training. Monthly records are maintained detailing the type and amount of ammunition used at the firing range. For EPCRA Section 313 reporting purposes, the ammunition records are input to the Department of Defense TRI-DDS software (EPA www.epa.gov/tri) to estimate the amount of EPCRA chemical used and released to the environment. Based on the results of the TRI-DDS software, a total of $10.0 \mathrm{lb}$ of lead compounds were emitted as fugitive air emissions from the firing range in 2006.

\subsubsection{Fuel Combustion}

In 2006, the Laboratory emitted lead compound emissions from the following combustion sources: the 
TA-21 steam plant, the asphalt plant, the TA-3 power plant, and from numerous small boilers and heaters. Emissions from the burning of both natural gas and diesel fuel were calculated. The total emissions from these combustion sources totaled $0.59 \mathrm{lb}$ of lead compound stack emissions.

In 2006, the Laboratory emitted a total of $10.59 \mathrm{lb}$ of lead compound emissions to the atmosphere. The fugitive emissions are from the firing range. The stack emissions include emissions from fuel oil/diesel combustion sources and natural gas combustion sources. Table 5-2 summarizes lead air emissions from the Laboratory as reported on the Form R.

Table 5-2 Lead Air Emissions from LANL in 2006

\begin{tabular}{lll}
\hline Emission Source & Total Lead Emissions $(\mathbf{l b})$ & Fugitive or Stack \\
\hline Firing Range & 10.0 & Fugitive \\
Fuel Combustion & 0.59 & Stack \\
Total & $\mathbf{1 0 . 5 9}$ & \\
\hline
\end{tabular}

\subsubsection{Releases to Water}

This section describes the amount of lead released to the environment from the Laboratory during 2006, as measured at LANL's National Pollutant Discharge Elimination System (NPDES) outfalls, which quantifies the amount of listed chemicals released due to facility operations during the reporting period.

During prior year assessments, a second data source has been included in release estimates. The quantity of lead present in surface and storm water has been estimated and reported. These estimates were derived from analytical and flow volume data collected at surface water sampling stations, as well as flow estimates for stations where flow is not measured. Further calculations were performed to quantify the amount of lead attributable to naturally occurring sources, and then convert the anthropogenic fraction to derive a mass. The detailed methodology for the analysis of lead in surface and storm water and mass calculations is documented in annual EPCRA Summary Reports for calendar years 2001 through 2005.

EPCRA requires the reporting of TRI listed chemicals released to the environment during the year in which they are originally released. The inclusion of surface and storm water data within the annual release data set is an overestimate as these data do not represent current year releases, but measure the migration and transport of existing contaminant inventory that 1) was released to the environment before initiation of annual EPCRA reporting, 2) is unrelated to the original environmental release, and 3) cannot be differentiated from, and likely effectively masks, actual environmental releases. Therefore, annual EPCRA reporting should only include annual original release data as directly measured at NPDES outfalls. 
NPDES outfall data, generated as part of the Laboratory's Outfall Monitoring Program, were obtained from the Water Quality Group. The tabular data from the NPDES program included total annual flows and lead analytical results from samples collected at a number of NPDES outfalls at LANL. Samples for lead were collected one to three times annually from 15 outfall locations, while weekly samples were collected from Outfall 051. Flow rate was reported by LANL in million gallons per year for each outfall location. For each NPDES outfall, lead discharges were calculated by multiplying the total yearly flow, in liters, for each outfall by the constituent concentration in milligrams per liter. The resulting mass from each outfall was then summed, resulting in a total discharge of $1.97 \mathrm{lbs}$ of lead from LANL NPDES outfalls in 2006.

For the EPCRA Section 313 Form R, Section 5.3 reporting, the total amount of lead released to each receiving stream is reported. For NPDES outfall data, the receiving stream associated with each sample location was determined through the use of the Laboratory's Environmental Surveillance Report maps and information received from LANL's Water Quality Group. The following table summarized the total lead discharged from LANL in NPDES outfalls within canyons on the Pajarito Plateau during 2006. Total lead release to streams was $1.97 \mathrm{lbs}$. Table 5-3 was used to complete Section 5.3.1 of the Form R.

Table 5-3 Lead Releases to Water in 2006 from LANL NPDES Outfalls

\begin{tabular}{ll}
\hline Canyon & LANL NPDES Outfalls Lead (lbs) \\
\hline Los Alamos Canyon Tributary to Rio Grande & 0.02 \\
Mortandad Canyon Tributary to Rio Grande & 1.94 \\
Sandia Canyon Tributary to Rio Grande & 0.0 \\
Water Canyon Tributary to Rio Grande & $7.70 \mathrm{E}-03$ \\
Total of NPDES Discharges & 1.97 \\
\hline
\end{tabular}

\subsubsection{Releases to Land}

Lead releases to land at the Laboratory occur as a result of firing range activities. Lead releases to land are based on the amount of munitions used during the year and the lead content of the munitions used. Lead content for munitions used at the Laboratory was estimated by matching the munitions types with those listed in the TRI-DDS. A total of $8,878 \mathrm{lb}$ of lead was released to land at the firing range at LANL in 2006.

\subsubsection{Offsite Waste Disposal}

The Solid Waste Operations Group provided waste characterization and disposal data for lead wastes that were shipped offsite in 2006. Laboratory and article exempt waste was removed from the data set. EPCRA article and laboratory exemptions have been documented in previous years' memos and are described in the EPA/TRI Guidance Document "Toxic Chemical Release Inventory Reporting Forms and Instructions for RY2006” (EPA-260-C-06-901) (EPA 2007). 
The data provided by Solid Waste Operations included the percent of lead for most of the waste shipments. However, this information was lacking for many of the waste items, and the Ecology and Air Quality Group had to obtain the necessary waste profile forms, which itemize waste constituent concentrations. For those items that listed the lead Resource Conservation and Recovery Act codes and did not list the concentrations of lead, waste profile forms were requested for waste items that weighed more than 1 kilogram. In most cases, the waste profile form provided sufficient information to complete the lead calculation. For some waste items, estimate of the $\%$ lead were made by matching it with similarly described waste shipments from previous years' analyses. For those waste items weighing less than 1 kilogram, lead concentrations were estimated based on the item description. For example, lead percentage by weight in waste items comprised of a chemical compound, such as lead nitrate, were determined from the Merck Index (1989). In other wastes, where the description provided sufficient information about the nature of the item (e.g., lead pellets), the percentage of lead was estimated (e.g., lead pellets $=100 \%$ lead $)$.

\subsubsection{Results}

The amount of lead contained in waste that was shipped offsite from the Laboratory in 2006 was 2,178 lbs. This total weight of lead was calculated by multiplying the total waste weight (kilograms) by the percentage of lead within each waste item, and then converted to pounds.

EPCRA reportable waste items shipped offsite from the Laboratory to several waste treatment/disposal facilities in 2006 are summarized in Table 5-4. As per EPCRA guidelines, only those disposal facilities that received more than $0.5 \mathrm{lbs}$ of lead in 2006 were included in the summary table and on the Form R.

The 2006 totals for lead are similar to 2005 and significantly lower than amounts shipped offsite from LANL in 2003 and 2004. The increase in waste shipments in 2003 and 2004 reflects LANL's efforts to expunge legacy waste, particularly lead bricks and lead shielding. No large-scale clean-up efforts were conducted in 2006. However, under the Laboratory's new management, numerous space walk-downs and inventories were initiated in 2006 and will result in cleanouts of unused/unwanted items over the next few years. Offsite waste disposal numbers are anticipated to increase with these efforts.

\subsubsection{Disposal Fate}

The EPCRA Form R requires information about each treatment/disposal facility that received waste from the Laboratory, including how much was sent to each waste treatment/disposal facility and additional information regarding waste treatment, recycling, or disposal conducted at each facility. A Waste Disposal/Treatment Code must be entered in Section 6.2.C of the Form $\mathrm{R}$ for each facility receiving waste. The Waste Disposal/Treatment Codes were updated by EPA in 2005 and are included on page 48 of the "Toxic Chemical Release Inventory Reporting Forms and Instructions for RY2006" (EPA-260-C-06-901) (EPA 2007) guidance document. 
Table 5-4 Summary of Waste Disposal Facilities Receiving LANL Waste in 2006

\begin{tabular}{|c|c|c|c|c|}
\hline Company & Address & Facility EPA ID & Ultimate Fate of Waster & Total Lead (Ib) \\
\hline $\begin{array}{l}\text { Clean Harbors, } \\
\text { Aragonite, LLC }\end{array}$ & $\begin{array}{l}11600 \text { North Aptus Rd., } \\
\text { Aragonite, UT } 84029\end{array}$ & UTD981552177 & Landfill & 187.3 \\
\hline $\begin{array}{l}\text { Clean Harbors, Grassy } \\
\text { Mountain, LLC }\end{array}$ & $\begin{array}{l}\text { Interstate } 80 \text { Exit } 41 \text {, Grassy } \\
\text { Mountain, UT } 84029\end{array}$ & UTD991301748 & Landfill & 485.2 \\
\hline $\begin{array}{l}\text { Diversified Scientific } \\
\text { Services, Inc. }\end{array}$ & $\begin{array}{l}657 \text { Gallaher Road, } \\
\text { Kingston, TN } 37763\end{array}$ & TND982109142 & Landfill & 3.20 \\
\hline $\begin{array}{l}\text { Energy Solutions, LLC } \\
\text { (formerly Envirocare of } \\
\text { Utah, Inc. }\end{array}$ & $\begin{array}{l}\text { Tooele County, I-80, Exit } 49 \text {, } \\
\text { Clive, UT } 84029\end{array}$ & UTD982598898 & Landfill & 31.22 \\
\hline $\begin{array}{l}\text { Onyx Environmental } \\
\text { Services, LLC }\end{array}$ & $\begin{array}{l}9131 \text { East 96TH Ave., } \\
\text { Henderson, CO } 80640\end{array}$ & COD980591184 & Landfill & $1,452.1$ \\
\hline $\begin{array}{l}\text { Onyx Special Services } \\
\text { Inc. }\end{array}$ & $\begin{array}{l}5752 \text { W. Jefferson St., } \\
\text { Phoenix, AZ } 85043\end{array}$ & AZ0000337360 & Metal Recovery & $0.04^{(\mathrm{a})}$ \\
\hline Perma-Fix, Inc. & $\begin{array}{l}1940 \text { NW 67th Place, } \\
\text { Gainesville, FL } 32653\end{array}$ & FLD980711071 & Landfill & 14.45 \\
\hline \multirow[t]{2}{*}{ Phibro-Tech, Inc. } & $\begin{array}{l}8851 \text { Dice Rd., Santa Fe } \\
\text { Springs, CA } 90670\end{array}$ & CAD008488025 & Metal Recovery & 4.57 \\
\hline & & Total & & 2,178 \\
\hline
\end{tabular}

(a) Releases of less than $0.1 \mathrm{lb}$ do not need to be included on the Form R reporting, per EPA Guidance.

\subsection{Other Information Provided on Form R Report}

Environmental releases of lead as air emissions, to surface waters, and onsite land releases were reported to be $10.6 \mathrm{lb}, 1.97 \mathrm{lb}$, and 8,878 lb, respectively. These values are included in Section 5 of the Form R, Quantity of the Toxic Chemical Entering Each Environmental Medium Onsite. A total of 2,178 $\mathrm{lb}$ of lead was reported in Section 6.2 of the Form R, Transfers to Other Offsite Locations.

Methods of treating lead in wastewater effluent before discharge were included in Section 7A of the Form $\mathrm{R}$, which details onsite waste treatment methods and efficiency. Wastewater from industrial processes at the Laboratory is discharged to the RLWTF before discharge to NPDES-permitted Outfall 051. The RLWTF conducts a series of treatment steps that reduce the amount of metals in the effluent. The wastewater stream goes through precipitation, filtration, and reverse osmosis treatment. All wastewater is sampled for lead before and after treatment. Based on analytical results for 2006, the RLWTF resulted in a $92 \%$ treatment efficiency of lead in the wastewater. Sections $7 \mathrm{~B}$ and $7 \mathrm{C}$ of the Form R relate to onsite energy recovery and recycling. The Laboratory performed no onsite processes applicable to these sections for lead in 2006.

Section 8 of the Form $\mathrm{R}$ refers to source reduction and recycling activities. The information provided by EPA for this section states that no energy recovery is possible for lead, either onsite or offsite. The Laboratory also reported no onsite recycling or treatment. Approximately $326 \mathrm{lb}$ of the lead shipped offsite were recycled.

Section 8.9 of the Form R reports the production or activity ratio, an estimated measure of production or 
activity involving the reported chemical, as compared to the previous year. Because the Laboratory is not a production facility, a surrogate measure was needed to complete this section of the Form R. To determine this value, the firing range was used as a representative activity that would maintain a consistent use of lead. The amount of lead munitions used in 2006 was divided by the amount used in 2005 to obtain an activity ratio of 1.25 .

\subsection{EPCRA SECTION 313 SUMMARY AND TRENDS}

The Laboratory has submitted EPCRA Section 313 data to EPA since 1987. From 1987 to 1994, this information was submitted by the UC, operator of LANL. Starting with reporting year 1995, EO 12856 required all federal facilities to comply with EPCRA Section 313 requirements. As of 1995, EPCRA Section 313 information for the Laboratory has also been submitted by the DOE. Historical information on LANL-reported Section 313 releases is included in the EPA TRI database and can be accessed at http://www.epa.gov/tri.

On April 21, 2000, EO 13148 was signed, which, in addition to requiring all federal facilities to comply with EPCRA Section 313 requirements, also required federal facilities to reduce releases of EPCRA Section 313 chemicals to the environment. In response to EO 13148, the DOE developed Pollution Prevention Leadership Goals that include the following:

- Reduce release of toxic chemicals subject to Toxic Chemical Release Inventory (EPCRA Section 313 ) reporting by $90 \%$ by 2005 , using a 1993 baseline.

The Laboratory has implemented numerous pollution prevention projects to reduce use and releases of EPCRA Section 313 chemicals. However, two regulatory changes made by EPA in recent years impact EPCRA Section 313 reporting:

- On October 19, 1999, EPA promulgated a final rule on PBTs. This rule added several chemicals to the EPCRA Section 313 list and established lower reporting thresholds for PBT chemicals. These lower thresholds became applicable in reporting year 2000.

- On January 17, 2001, EPA expanded the PBT rule to reduce the EPCRA Section 313 reporting threshold for lead and lead compounds to $100 \mathrm{lb}$ (from 10,000 lb). The new lead threshold became applicable with reporting year 2001.

As a result of these regulatory changes, the Laboratory has triggered EPCRA Section 313 reporting for lead and mercury in recent years. The regulatory changes resulted in reporting thresholds of $10 \mathrm{lb}$ for mercury and $100 \mathrm{lb}$ for lead. Therefore, for the past six years LANL has submitted environmental release data on lead and, three out of the last six years, has reported on mercury. Figure 6-1 provides a summary of LANL-reported releases for the period from 1993 through 2006.

Several points are worth noting from this chart:

- In the early 1990s, the Laboratory implemented a new wastewater disinfection system that eliminated the use of chlorine. Chlorine gas was replaced with bromine tablets and mixed oxidants generated from sodium chloride. This pollution prevention project decreased use of chlorine to well below reporting thresholds.

- In the late 1990 s, the Laboratory implemented a NARS to reduce the amount of new nitric acid needed for plutonium processing. This closed-loop recycle system greatly reduced the need to purchase nitric acid, and due to recycling efforts, nitric acid use was below reporting thresholds 
for several years. However, in 2003 and 2004 a new process to convert weapons-grade plutonium to MOx fuels for nuclear power plants was implemented. Due to quality specifications and facility constraints, this project was unable to use recycled nitric acid. Therefore, nitric acid was reportable for 2003 and 2004.

- In 2005, the plutonium processing facility had very limited operations due to ongoing facility maintenance and equipment upgrades. Therefore, nitric acid use was well below reporting thresholds for 2005. In late 2006 the maintenance and equipment upgrades were completed and operations restarted. However, nitric acid use for 2006 was still just below reporting thresholds.

- Because there were no identified users of recycled nitric acid, and limited storage capacity, in 2004, spent nitric acid from plutonium processing was sent to the RLWTF for treatment and disposal. Through the treatment process nitric acid was neutralized and resulted in formation of nitrate compounds. For the first time in 2004, nitrate compounds were manufactured above reportable quantities and triggered reporting.

- Although the use of lead and lead compounds has been relatively constant over the years at the Laboratory, the threshold for reporting was lowered to $100 \mathrm{lb}$ in 2001. The Laboratory first began EPCRA Section 313 reporting on lead in that year. About that same time, LANL made a concerted effort to reduce onsite inventory of lead bricks and shielding that is no longer needed. Much of this lead shielding is radioactively contaminated and cannot be recycled. Therefore, large amounts of legacy lead were shipped offsite for disposal and reported on the Form Rs.

- The largest use of mercury at the Laboratory is in the LANSCE shutter system. Reservoirs of mercury are used as shields on the neutron beam shutter system. Each reservoir is a closed system and only opened occasionally when minor repairs or maintenance are needed. Mercury has only triggered reporting during the years that maintenance activities have occurred on the shutter systems. Environmental releases of mercury are very low.

Another metric used at LANL is tracking of EPCRA Section 313 reportable chemical use. Figure 6-2 shows the amount of reportable chemicals used at LANL from 1993 through 2006. LANL set a pollution prevention goal of reducing the use of EPCRA Section 313 reportable chemicals by $90 \%$ by 2005 using 1993 as a baseline. Although the 2005 date for reaching this metric has passed, we are showing the graph with 2006 data to provide additional perspective on the Laboratory's continued efforts at pollution prevention. The straight blue line shows the $90 \%$ reduction goal. The pink line shows the actual amount of EPCRA Section 313 reportable chemicals used each year. Each year LANL evaluates EPCRA Section 313 reportable chemical use and uses this information to prioritize pollution prevention projects to reduce use of these chemicals. As shown in Figure 6-2, LANL has made good progress towards the 90\% chemical use reduction goal. However, the MOx project in 2003 and 2004 was not able to recycle nitric acid for reuse and resulted in a substantial increase in use of nitric acid. 


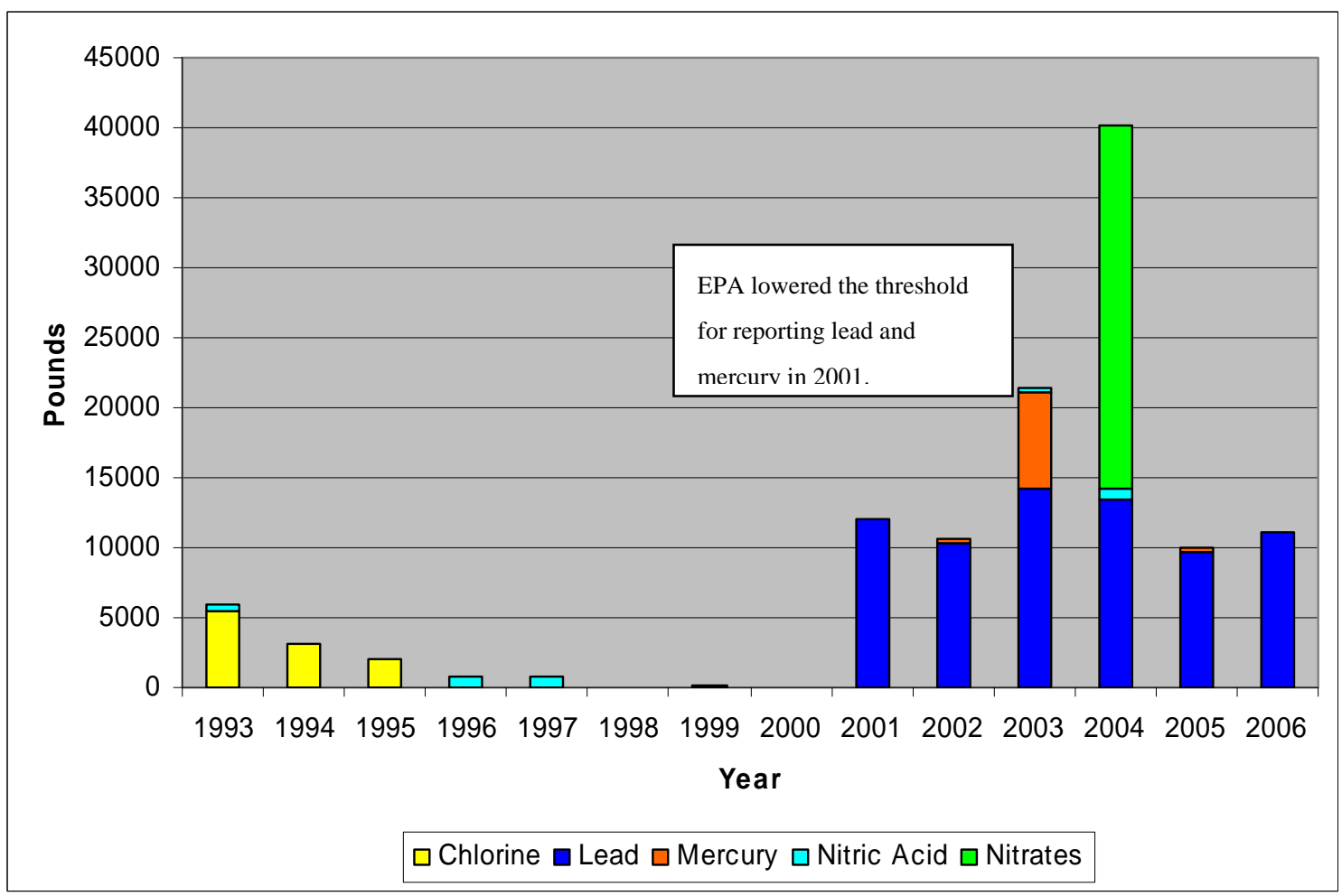

Note: For 2003 through 2006 one-time waste disposal of lead from decontamination and demolition activities is not included on this chart.

Figure 6-1 Trends in LANL's reported releases to EPA TRI.

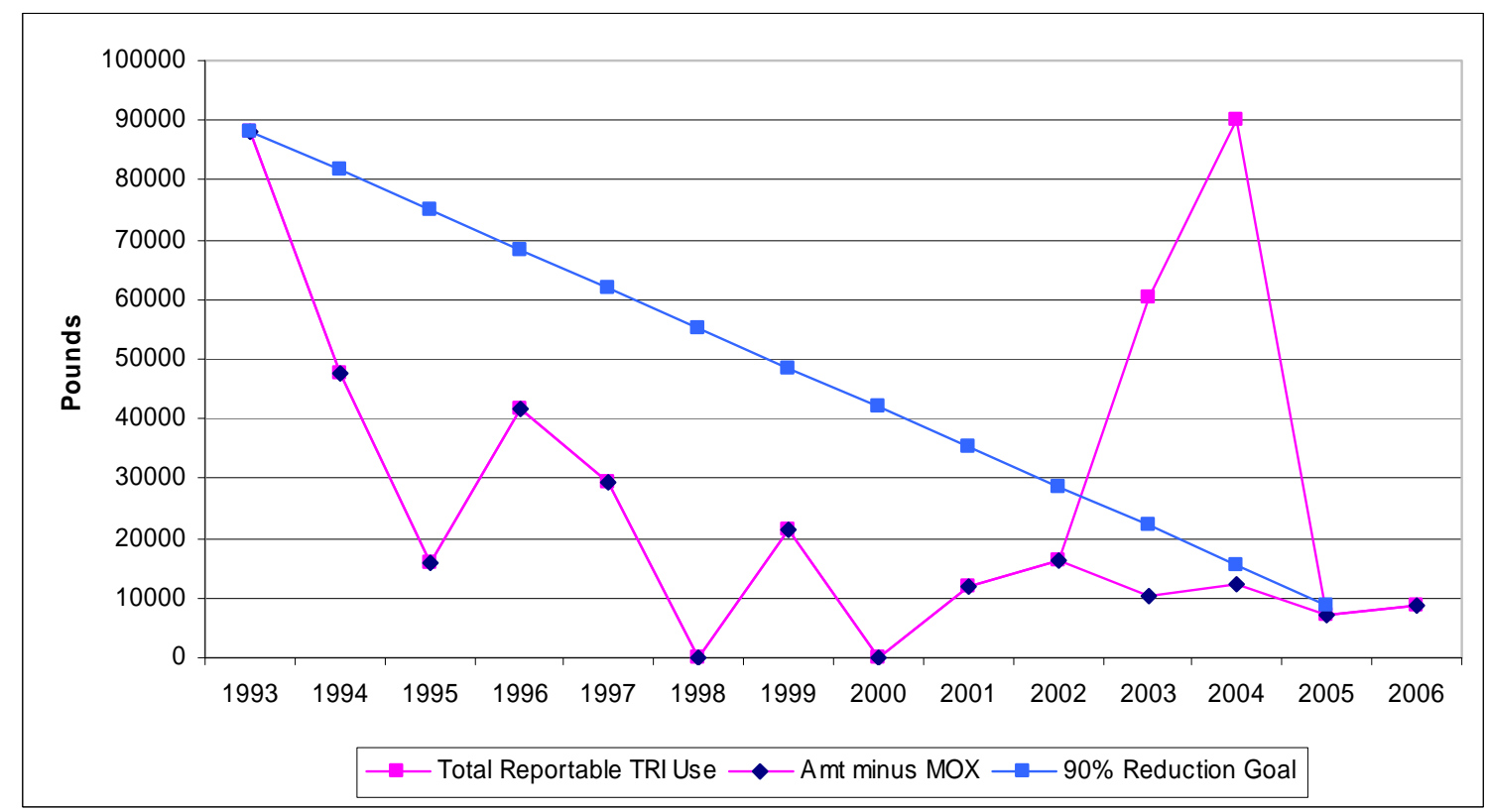

Figure 6-2 Trends in TRI reportable chemical use at LANL. 


\subsection{REFERENCES}

American Society of Mechanical Engineers, 1995. "Relationship Between Chlorine in Waste Streams and Dioxin Emissions from Combustors," CRTD Vol. 36 (December 1995).

Chevron-Texaco, 2001. "Guidance Recommendations for SARA 313 Reporting of Polycyclic Aromatic Compounds (PACs) and Benzo(g,h,i)perylene" (May 2001).

EPA (U.S. Environmental Protection Agency), 1998a. "Compilation of Air Pollutant Emission Factors," AP-42, Chapter 1.3-Fuel Oil Combustion (September 1998).

EPA (U.S. Environmental Protection Agency), 1998b. "Compilation of Air Pollutant Emission Factors," AP-42, Fifth Edition, Section 1.4-Natural Gas Combustion (July 1998).

EPA (U.S. Environmental Protection Agency), 1998c. "Emission Factors for the Disposed of Energetic Materials by Open Burn and Open Detonation" (1998).

EPA (U.S. Environmental Protection Agency), 1999. "Emergency Planning and Community Right-toKnow Act—Section 313: Guidance for Reporting Hydrochloric Acid,” EPA 745-B-014 (December 1999).

EPA (U.S. Environmental Protection Agency), 2000a. "Emergency Planning and Community Right-ToKnow Act-Section 313: Guidance for Reporting Toxic Chemicals within the Dioxin and Dioxin-like Compounds Category,” EPA 745-B-00-021 (December 2000).

EPA (U.S. Environmental Protection Agency), 2000b. "List of Toxic Chemicals within the Water Dissociable Nitrate Compounds Category and Guidance for Reporting," EPA 745-R-00-006 (December 2000).

EPA (U.S. Environmental Protection Agency), 2001a. "EPCRA Mercury Guidance Document," EPA260-B-01-004, Table 3-1 (August 2001).

EPA (U.S. Environmental Protection Agency), 2001b. "Emergency Planning and Community Right-toKnow Act-Section 313: Guidance for Reporting Toxic Chemicals: Polycyclic Aromatic Compounds Category," EPA 260-B-01-03 (June 2001).

EPA (U.S. Environmental Protection Agency), 2001c. "Emergency Planning and Community Right-toKnow Act-Section 313: Guidance for Reporting Toxic Chemicals: Pesticides and Other Persistent Bioaccumulative Toxic (PBT) Chemicals," EPA 260-B-01-005 (August 2001).

EPA (U.S. Environmental Protection Agency), 2001d, "Emergency Planning and Community Right-toKnow Act-Section 313: Guidance for Reporting Releases and Other Waste Management Quantities of Toxic Chemicals: Lead and Lead Compounds," EPA 260-B-01-027 (December 2001).

EPA (U.S. Environmental Protection Agency), 2004. "Hot Mix Asphalt Plants," AP-42, Fifth Edition, Table 11.1-11 (March 2004).

EPA (U.S. Environmental Protection Agency), 2006. “Toxic Chemical Release Inventory Reporting Form R and Instructions,” Revised 2005 Version, EPA 260-B-06-001 (January 2006).

EPA (U.S. Environmental Protection Agency), 2007. "Toxic Chemical Release Inventory Reporting Forms and Instructions for RY2006.” EPA-260-C-06-901 (January 2007). 
APPENDIX A CHEMICAL PROCUREMENTS FOR 2006 
Appendix A:

EPCRA Section 313 Chemicals Used or Prcured in 2006

\begin{tabular}{|c|c|c|c|}
\hline CAS Number & Chemical Name & $\begin{array}{l}\text { EPCRA Threshold } \\
\text { (lb) }\end{array}$ & $\begin{array}{l}2006 \text { Amount } \\
\text { Purchased or } \\
\text { Used (lb) }\end{array}$ \\
\hline 7664-93-9 & Sulfuric acid (aerosol forms only) & 10000 & 14004.37 \\
\hline $7647-01-0$ & Hydrochloric acid (aerosol forms only) & 10000 & 6136.52 \\
\hline $7697-37-2$ & Nitric acid & 10000 & 3272.39 \\
\hline $67-63-0$ & Isopropyl alcohol (mfg-strong acid process) & 10000 & 2438.89 \\
\hline $75-09-2$ & Dichloromethane & 10000 & 2267.45 \\
\hline Cobalt Compounds & Cobalt Compounds & 10000 & 2256.66 \\
\hline 75-45-6 & Chlorodifluoromethane & 10000 & 1424.45 \\
\hline $67-56-1$ & Methanol & 10000 & 1390.53 \\
\hline Manganese Compounds & Manganese Compounds & 10000 & 1357.46 \\
\hline $7429-90-5$ & Aluminum (fume or dust) & 10000 & 982.28 \\
\hline $75-05-8$ & Acetonitrile & 10000 & 888.23 \\
\hline 107-21-1 & Ethylene glycol & 10000 & 861.31 \\
\hline $872-50-4$ & N-Methyl-2-pyrrolidone & 10000 & 824.66 \\
\hline $78-93-3$ & Methyl ethyl ketone & 10000 & 753.68 \\
\hline 7664-38-2 & Phosphoric acid & 10000 & 607.62 \\
\hline $110-54-3$ & n-Hexane & 10000 & 599.63 \\
\hline $107-06-2$ & 1,2-Dichloroethane & 10000 & 517.69 \\
\hline Nickel Compounds & Nickel Compounds & 10000 & 474.51 \\
\hline $7664-39-3$ & Hydrogen fluoride & 10000 & 463.43 \\
\hline Polychlorinated Alkanes & Polychlorinated alkanes (C10 to C13) & 10000 & 432.89 \\
\hline Barium Compounds & Barium Compounds & 10000 & 354.32 \\
\hline 108-88-3 & Toluene & 10000 & 235.15 \\
\hline $79-01-6$ & Trichloroethylene & 10000 & 234.45 \\
\hline $67-66-3$ & Chloroform & 10000 & 209.45 \\
\hline $7632-00-0$ & Sodium nitrite & 10000 & 150.34 \\
\hline 7664-41-7 & Ammonia & 10000 & 133.26 \\
\hline 75-71-8 & Dichlorodifluoromethane & 10000 & 120 \\
\hline $333-41-5$ & Diazinon & 10000 & 119.94 \\
\hline Zinc Compounds & Zinc Compounds & 10000 & 115.89 \\
\hline $76-13-1$ & Freon 113 & 10000 & 110.24 \\
\hline $95-63-6$ & 1,2,4-Trimethylbenzene & 10000 & 108.48 \\
\hline $7782-50-5$ & Chlorine & 10000 & 95.15 \\
\hline Nitrate Compounds & Nitrate compounds (water dissociable) & 10000 & 91.94 \\
\hline 71-43-2 & Benzene & 10000 & 89.26 \\
\hline Copper Compounds & Copper Compounds & 10000 & 75.25 \\
\hline 1344-28-1 & Aluminum oxide (fibrous forms) & 10000 & 69.51 \\
\hline Cyanide Compounds & Cyanide Compounds & 10000 & 63.05 \\
\hline $68-12-2$ & $\mathrm{~N}, \mathrm{~N}$-Dimethylformamide & 10000 & 55.31 \\
\hline $71-55-6$ & 1,1,1-Trichloroethane & 10000 & 52.25 \\
\hline Glycol Ethers Compounds & Glycol Ethers & 10000 & 34.61 \\
\hline Silver Compounds & Silver Compounds & 10000 & 27 \\
\hline $110-86-1$ & Pyridine & 10000 & 21.05 \\
\hline $7440-41-7$ & Beryllium & 10000 & 19.99 \\
\hline 7783-06-4 & Hydrogen sulfide & 10000 & 16.51 \\
\hline $7440-50-8$ & Copper & 10000 & 16.01 \\
\hline 1634-04-4 & Methyl tert-butyl ether & 10000 & 14.85 \\
\hline $7439-92-1$ & Lead & 100 & 13.42 \\
\hline $123-91-1$ & 1,4-Dioxane & 10000 & 12.67 \\
\hline $79-06-1$ & Acrylamide & 10000 & 10.98 \\
\hline Warfarin and salts & Warfarin and salts & 10000 & 9.76 \\
\hline $95-50-1$ & 1,2-Dichlorobenzene & 10000 & 9.74 \\
\hline 64-18-6 & Formic acid & 10000 & 9.42 \\
\hline $123-31-9$ & Hydroquinone & 10000 & 8.75 \\
\hline $108-10-1$ & Methyl isobutyl ketone & 10000 & 7.03 \\
\hline Chromium Compounds & Chromium Compounds & 10000 & 7.01 \\
\hline
\end{tabular}


Appendix A:

EPCRA Section 313 Chemicals Used or Prcured in 2006

\begin{tabular}{|c|c|c|c|}
\hline CAS Number & Chemical Name & $\begin{array}{l}\text { EPCRA Threshold } \\
\text { (lb) }\end{array}$ & $\begin{array}{l}2006 \text { Amount } \\
\text { Purchased or } \\
\text { Used (lb) }\end{array}$ \\
\hline $110-82-7$ & Cyclohexane & 10000 & 6.84 \\
\hline $7440-39-3$ & Barium & 10000 & 6.6 \\
\hline $50-00-0$ & Formaldehyde & 10000 & 6.09 \\
\hline $75-65-0$ & tert-Butyl alcohol & 10000 & 5.93 \\
\hline $77-78-1$ & Dimethyl sulfate & 10000 & 5.86 \\
\hline $56-23-5$ & Carbon tetrachloride & 10000 & 5.61 \\
\hline $111-42-2$ & Diethanolamine & 10000 & 5.6 \\
\hline $7440-02-0$ & Nickel & 10000 & 4.55 \\
\hline $108-31-6$ & Maleic anhydride & 10000 & 4.44 \\
\hline $7440-62-2$ & Vanadium (fume or dust) & 10000 & 4.12 \\
\hline $100-42-5$ & Styrene & 10000 & 3.98 \\
\hline $1330-20-7$ & Xylene (mixed isomers) & 10000 & 3.78 \\
\hline $124-40-3$ & Dimethylamine & 10000 & 3.48 \\
\hline Cadmium Compounds & Cadmium Compounds & 10000 & 2.59 \\
\hline $74-88-4$ & Methyl iodide & 10000 & 2.49 \\
\hline $108-90-7$ & Chlorobenzene & 10000 & 2.43 \\
\hline Chlorophenols & Chlorophenols & 10000 & 2.42 \\
\hline Beryllium Compounds & Beryllium Compounds & 10000 & 2.13 \\
\hline $51-79-6$ & Urethane & 10000 & 2.01 \\
\hline $141-32-2$ & Butyl acrylate & 10000 & 1.97 \\
\hline $71-36-3$ & n-Butyl alcohol & 10000 & 1.95 \\
\hline Lead & Lead Compounds & 100 & 1.93 \\
\hline $106-93-4$ & 1,2-Dibromoethane & 10000 & 1.92 \\
\hline Antimony Compounds & Antimony Compounds & 10000 & 1.89 \\
\hline $79-34-5$ & 1,1,2,2-Tetrachloroethane & 10000 & 1.75 \\
\hline $121-44-8$ & Triethylamine & 10000 & 1.6 \\
\hline $10034-93-2$ & Hydrazine sulfate & 10000 & 1.32 \\
\hline $98-95-3$ & Nitrobenzene & 10000 & 1.32 \\
\hline 554-13-2 & Lithium carbonate & 10000 & 1.31 \\
\hline Mercury Compounds & Mercury Compounds & 10 & 1.29 \\
\hline Selenium Compounds & Selenium Compounds & 10000 & 1.13 \\
\hline $62-53-3$ & Aniline & 10000 & 1.11 \\
\hline $90-04-0$ & o-Anisidine & 10000 & 1.1 \\
\hline $90-43-7$ & 2-Phenylphenol & 10000 & 1.1 \\
\hline $7440-47-3$ & Chromium & 10000 & 1.1 \\
\hline $76-02-8$ & Trichloroacetyl chloride & 10000 & 0.89 \\
\hline $7440-66-6$ & Zinc (fume or dust) & 10000 & 0.77 \\
\hline $26628-22-8$ & Sodium azide (Na(N3)) & 10000 & 0.72 \\
\hline $7637-07-2$ & Boron trifluoride & 10000 & 0.66 \\
\hline Diisocyanates (includes 20 che & Diisocyanates (includes 20 chemicals) & 10000 & 0.66 \\
\hline $62-56-6$ & Thiourea & 10000 & 0.66 \\
\hline $7439-96-5$ & Manganese & 10000 & 0.55 \\
\hline $7440-48-4$ & Cobalt & 10000 & 0.53 \\
\hline $62-55-5$ & Thioacetamide & 10000 & 0.44 \\
\hline $7782-49-2$ & Selenium & 10000 & 0.44 \\
\hline $94-75-7$ & $2,4-\mathrm{D}$ & 10000 & 0.44 \\
\hline $72-57-1$ & Trypan blue & 10000 & 0.44 \\
\hline $75-15-0$ & Carbon disulfide & 10000 & 0.33 \\
\hline $120-12-7$ & Anthracene & 10000 & 0.28 \\
\hline $60-35-5$ & Acetamide & 10000 & 0.24 \\
\hline Arsenic Compounds & Arsenic Compounds & 10000 & 0.23 \\
\hline $79-10-7$ & Acrylic acid & 10000 & 0.22 \\
\hline $302-01-2$ & Hydrazine & 10000 & 0.22 \\
\hline $55-21-0$ & Benzamide & 10000 & 0.22 \\
\hline $106-44-5$ & p-Cresol & 10000 & 0.22 \\
\hline
\end{tabular}


Appendix A:

EPCRA Section 313 Chemicals Used or Prcured in 2006

\begin{tabular}{|c|c|c|c|}
\hline CAS Number & Chemical Name & $\begin{array}{l}\text { EPCRA Threshold } \\
\text { (lb) }\end{array}$ & $\begin{array}{l}2006 \text { Amount } \\
\text { Purchased or } \\
\text { Used (lb) }\end{array}$ \\
\hline $104-94-9$ & p-Anisidine & 10000 & 0.22 \\
\hline $7440-22-4$ & Silver & 10000 & 0.22 \\
\hline $75-07-0$ & Acetaldehyde & 10000 & 0.2 \\
\hline Thallium Compounds & Thallium Compounds & 10000 & 0.16 \\
\hline $13463-40-6$ & Iron, pentacarbonyl- & 10000 & 0.14 \\
\hline $106-50-3$ & p-Phenylenediamine & 10000 & 0.11 \\
\hline $7726-95-6$ & Bromine & 10000 & 0.11 \\
\hline $7440-28-0$ & Thallium & 10000 & 0.06 \\
\hline $108-45-2$ & 1,3-Phenylenediamine & 10000 & 0.05 \\
\hline $61-82-5$ & Amitrole & 10000 & 0.05 \\
\hline 1120-71-4 & Propane sultone & 10000 & 0.05 \\
\hline $100-41-4$ & Ethylbenzene & 10000 & 0.04 \\
\hline $7440-38-2$ & Arsenic & 10000 & 0.04 \\
\hline $107-02-8$ & Acrolein & 10000 & 0.04 \\
\hline $7440-36-0$ & Antimony & 10000 & 0.02 \\
\hline 7723-14-0 & Phosphorus (yellow or white) & 10000 & 0.02 \\
\hline $92-87-5$ & Benzidine & 10000 & 0.02 \\
\hline 88-89-1 & Picric acid & 10000 & 0.02 \\
\hline $7550-45-0$ & Titanium tetrachloride & 10000 & 0.02 \\
\hline $107-05-1$ & Allyl chloride & 10000 & 0.01 \\
\hline $1464-53-5$ & Diepoxybutane & 10000 & 0.01 \\
\hline $680-31-9$ & Hexamethylphosphoramide & 10000 & 0.01 \\
\hline 121-14-2 & 2,4-Dinitrotoluene & 10000 & 0.01 \\
\hline $139-13-9$ & Nitrilotriacetic acid & 10000 & 0.01 \\
\hline
\end{tabular}



APPENDIX B FORM R REPORT FOR LEAD 


\title{
DISK
}

U.S. DEPARTMENT OF ENERGY, LOS ALAMOS

NATIONAL LABORATORY

528 35TH STREET

LOS ALAMOS, NM 87544

87544SDLSL52835

June 18, 2007

Don Shainin, HazMat Coordinator

Office of Emergency Services \& Security

13 Bataan Blvd.

Santa Fe, NM 87508

To Whom It May Concem:

Enclosed please find one (1) microcomputer diskette containing toxic chemical release reporting information for:

\section{U.S. DEPARTMENT OF ENERGY, LOS ALAMOS NATIONAL LABORATORY}

This information is submitted as required under section 313 of the Emergency Planning and Community Right-to-Know Act of 1986 and the Pollution Prevention Act of 1990.

We are submitting a total of 1 chemical report(s) for our facility.

These 1 chemical report(s) are described below:

$\frac{\text { TRI Chemical or Chemical Categon }}{\text { Lead }} \quad \frac{\text { Reporting Year }}{2006} \quad \frac{\text { CAS Number }}{7439 \cdot 92-1} \quad \frac{\text { Report }}{\text { Form } R}$

Our technical point of contact is:

\author{
GENE TURNER \\ (505) 667-5794 \\ GTURNER@DOEAL.GOV
}

and is available should any questions or problems arise in the processing of this diskette.

If the enclosed diskette contains one or more Form R chemicals, then I hereby certify that I have reviewed the enclosed documents and that, to the best of my knowledge and belief, the submitted information is true and complete and that the amounts and values in this report(s) are accurate based on reasonable estimates using data available to the preparers of this report(s).

If the enclosed diskette contains one or more Form $A$ chemicals, then:

Pursuant to 40 CFR 372.27 (a)(1), "I hereby certify that to the best of my knowledge and belief for the toxic chemical(s) listed in this statement, for this reporting year, the annual reportable amount for each chemical, as defined in 40 CFR $372.27(a)(1)$, did not exceed 5,000 pounds, which included no more than 2,000 pounds of total disposal or other releases to the environment, and that the chemical was manufactured, or processed, or otherwise used in an amount not exceeding 1 million pounds during this reporting year;" and/or

Pursuant to 40 CFR 372.27 (a)(2), "I hereby certify that to the best of my knowledge and belief for the toxic chemical(s) of special concern listed in this statement, there were zero disposals or other releases to the environment (including disposals or other releases that resulted from catastrophic events) for this reporting year, the "Annual Reportable Amount of a Chemical of Special Concern" for each such chemical, as defined in 40 CFR $372.27(a)(2)$, did not exceed 500 pounds for this reporting year, and that the chemical was manufactured, or processed, or otherwise used in an amount not exceeding 1 million pounds during this reporting year."

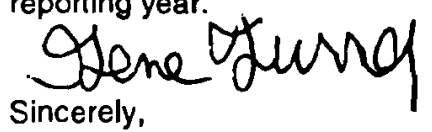

GENE TURNEA

ENVIRONMENTAL PERMITTING MANAGER

Enclosure: Diskette

TRI-ME RY2006 7.0.6

Page 1 of 1

06/18/2007 03:27 PM 
Cy:

G. Rael, DOE-LASO, A316

V. Bynum, PADOPS, A102

R.Watkins, ADESH\&Q, K491

P. Wardwell, LC-LESH, A187

V. George, ENV-DO, J978

D. Wilburn, ENV-EAQ, J978

D. Janecky, ENV-EAQ, J978

S. Story, ENV-EAQ, J978

M. Stockton, ENV-EAQ, J978

W. Whetham, ENV-EAQ, J978

EPCRA Project File, J978

ENV-EAQ File, J978 

Snited bates
Environmental Protection
Agency
Anow Act of 1986, also known as Title Ill of the Supertund
Amendments and Reauthorization Act TRI Facility ID Number

WHERE TO SEND COMPLETED FORMS: 1. TRI Data Processing Center 2. APPROPRIATE STATE OFFICE

\begin{tabular}{l|l} 
(See instructions in Appendix $F$ ) & is a revision \\
\cline { 2 - 2 } & For EPA use only \\
\hline
\end{tabular}

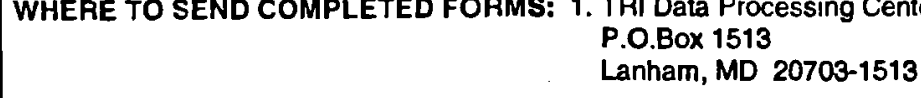

\begin{tabular}{|c|c|c|c|c|c|}
\hline & Are you claiming the toxic chemical identifie & on page 2 trade secret? & & Is this copy $\square$ Sanitlzed & Unsanitized \\
\hline 2.1 & $\begin{array}{l}\square \text { Yes (Answer question 2.2; } \\
\text { Attach substantiation forms) }\end{array}$ & $\begin{array}{cc}X & \text { NO (Do not answer 2.2; } \\
\text { Go to Section 3) }\end{array}$ & 2.2 & (Answer only if "YES" in 2.1) & \\
\hline
\end{tabular}

\section{Important: See instructions to determine when "Not Applicable (NA)" boxes should be checked. PART I. FACILITY IDENTIFICATION INFORMATION}

SECTION 3. CERTIFICATION (Important: Read and sign after completing all form sections.)

I hereby certify that I have reviewed the atlached documents and that, to the best of my knowledge and belief, the submitted information is true and complete and that the amounts and values in this report are accurate based on reasonable estimates using data available to the preparers of this report.

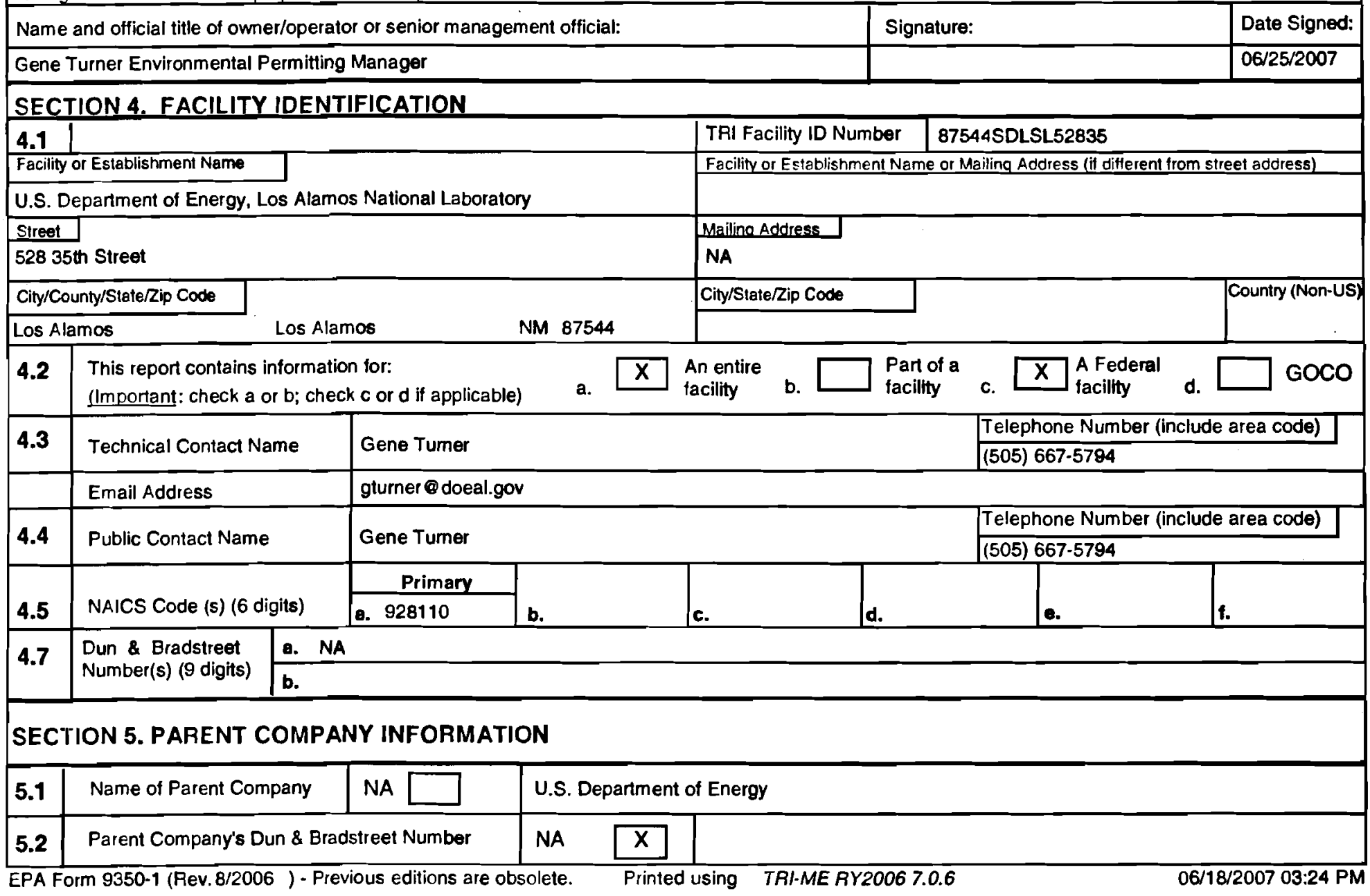




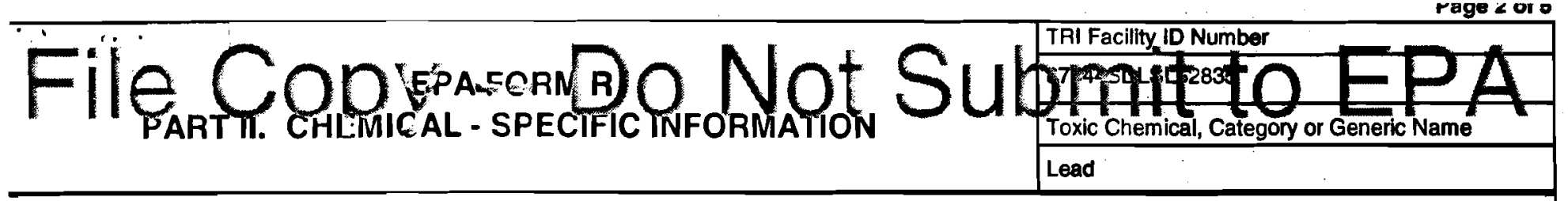

\section{SECTION 1. TOXIC CHEMICAL IDENTITY}

(Important: DO NOT complete this section If you completed Section 2 below.)

\begin{tabular}{|c|c|c|c|c|c|c|c|c|c|c|c|c|c|c|c|c|c|}
\hline \multirow[b]{2}{*}{1.1} & \multicolumn{17}{|c|}{ CAS Number (Imponant: Enter only one number exactly as it appears on the Section 313 list. Enter category code if reporting a chemical category.) } \\
\hline & \multicolumn{17}{|c|}{$7439-92-1$} \\
\hline \multirow[b]{2}{*}{1.2} & \multicolumn{17}{|c|}{ Toxic Chemical or Chemical Category Name (Important: Enter only one name exactly as it appears on the Section 313 list.) } \\
\hline & \multicolumn{17}{|l|}{ Lead } \\
\hline \multirow{2}{*}{1.3} & \multicolumn{17}{|c|}{ Generic Chemical Name (important: Complete only if Part 1, Section 2.1 is checked 'Yes". Generic Name must be structurally descriptivo.) } \\
\hline & \multicolumn{17}{|c|}{ NA } \\
\hline 1.4 & \multicolumn{17}{|c|}{$\begin{array}{l}\text { Distribution of Each Member of the Dioxin and Dioxin-llke Compounds Category. } \\
\text { (If there are any numbers in boxes } 1-17 \text {, then every field must be filled in with either } 0 \text { or some number between } 0.01 \text { and } 100 \text {. Distribution should be } \\
\text { reported in percentages and the total should equal } 100 \% \text {. If you do not have speciation data available, indicate NA.) }\end{array}$} \\
\hline & 1 & 2 & 3 & 4 & 5 & 6 & 7 & 8 & $\boldsymbol{\theta}$ & 10 & 11 & 12 & 13 & 14 & 15 & 16 & 17 \\
\hline \multicolumn{18}{|l|}{ NA } \\
\hline \multicolumn{18}{|c|}{ SECTION 2. MIXTURE COMPONENT IDENTITY } \\
\hline \multirow[b]{2}{*}{2.1} & \multicolumn{17}{|c|}{ Generic Chemical Name Provided by Supplier (Important: Maximum of 70 characters, including numbers, letters, spaces, and punctuation.) } \\
\hline & \multicolumn{17}{|l|}{ NA } \\
\hline
\end{tabular}

\section{SECTION 3. ACTIVITIES AND USES OF THE TOXIC CHEMICAL AT THE FACILITY} (Important: Check all that apply.)

\begin{tabular}{|l|l|l|l|}
\hline 3.1 & Manufacture the toxic chemical: & 3.2 & Process the toxic chemical: \\
\hline a. $\square$ Produce b. $\square$ Import & \\
If produce or import: & a. $\square$ As a reactant \\
c. $\square$ For on-site use/processing & b. $\square$ As a formulation component \\
d. $\square$ For sale/distribution & c. $\square$ As an article component \\
e. $\square$ As a byproduct & d. $\square$ Repackaging \\
f. $\square$ As an impurity & e. $\square$ As an impurity
\end{tabular}

\begin{tabular}{|l|l} 
3.3 & Otherwise use the toxic chemical: \\
\hline
\end{tabular}

a. $\square$ As a chemical processing ald
b. $\square$ As a manufacturing aid
c. $x$ Ancillary or other use

SECTION 4. MAXIMUM AMOUNT OF THE TOXIC CHEMICAL ONSITE AT ANY TIME DURING THE CALENDAR YEAR
\begin{tabular}{l|c|}
\hline 4.1 & 05 \\
\hline
\end{tabular}
(Enter two-digit code from instruction package.)
SECTION 5. QUANTITY OF THE TOXIC CHEMICAL ENTERING EACH ENVIRONMENTAL MEDIUM ONSITE

\begin{tabular}{|c|c|c|c|c|c|}
\hline & & & $\begin{array}{l}\text { A. Total Release (pounds/year") } \\
\text { (Enter range code or estimate*") }\end{array}$ & $\begin{array}{l}\text { B. Basis of Estimate } \\
\text { (enter code) }\end{array}$ & C. \% From Stormwater \\
\hline 5.1 & $\begin{array}{l}\text { Fugitive or non-point } \\
\text { air emissions }\end{array}$ & NA & 10 & C & \\
\hline 5.2 & $\begin{array}{l}\text { Stack or point } \\
\text { air emissions }\end{array}$ & NA & 0.6 & $\mathbf{E}$ & \\
\hline 5.3 & \multicolumn{2}{|c|}{$\begin{array}{l}\text { Discharges to receiving streams or } \\
\text { water bodies (enter one name per box) }\end{array}$} & \multicolumn{2}{|c|}{$\begin{array}{ll} \\
4\end{array}$} & 8 \\
\hline \multicolumn{3}{|c|}{ Stream or Water Body Name } & & & \\
\hline 5.3.1 & \multicolumn{2}{|c|}{ LOS ALAMOS CANYON TRIEUTARY TO RIO } & 0.02 & M & 0 \\
\hline 5.3.2 & \multicolumn{2}{|c|}{ WATER CANYON TRIBUTARY TO RIO GRA } & 0.01 & $M$ & 0 \\
\hline 5.3.3 & \multicolumn{2}{|c|}{ MORTANDAD TRIBUTARY TO RIO GRANDE } & 1.94 & $M$ & 0 \\
\hline \multicolumn{5}{|c|}{$\begin{array}{l}\text { If additional pages of Part II, Section } 5.3 \text { are attached, indicate the total number of pages in this box } \\
\text { and indicate the Part II, Section } 5.3 \text { page number in this box. } \\
\text { (example: } 1,2,3 \text {, etc.) }\end{array}$} & \\
\hline
\end{tabular}

EPA Form 9350-1 (Rev. 8/2006 ) - Previous editions are obsolete.

- For Dioxin or Dioxin-like compounds, report in grams/year ". Range Codes: $A=1-10$ pounds; $B=11-499$ pounds; $C=500-999$ pounds. 
SECTION 5. QUANTITY OF THE TOXIC CHEMICAL ENTERING EACH ENVIRONMENTAL MEDIUM ONSITE (ContinUEd)

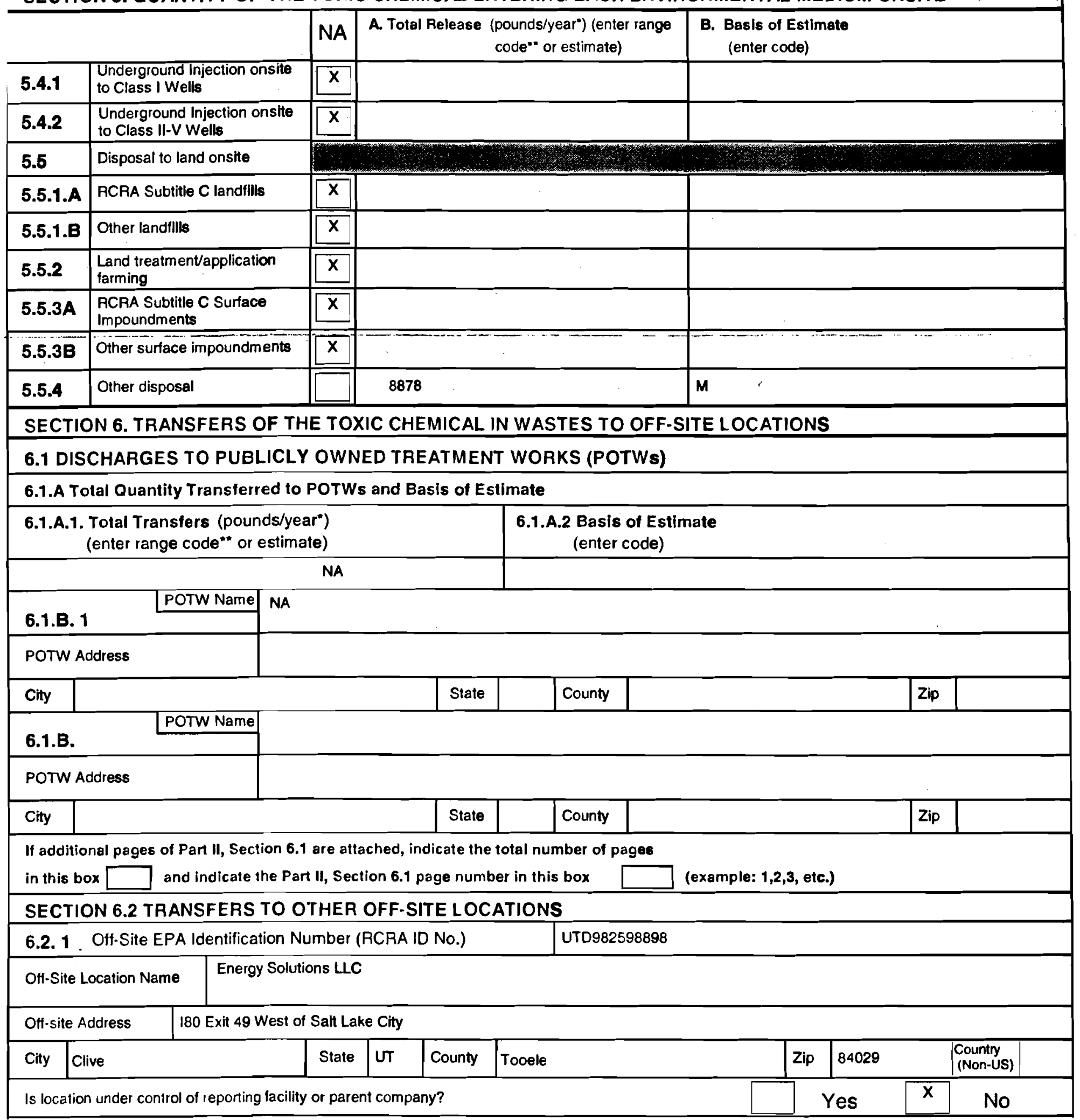

EPA Form 9350-1 (Rev. 8/2006) - Previous editions are obsolete.

- For Dioxin or Dioxin-like compounds, report in grams/year - Range Codes: $A=1-10$ pounds; $B=11-499$ pounds; $C=500-999$ pounds. 


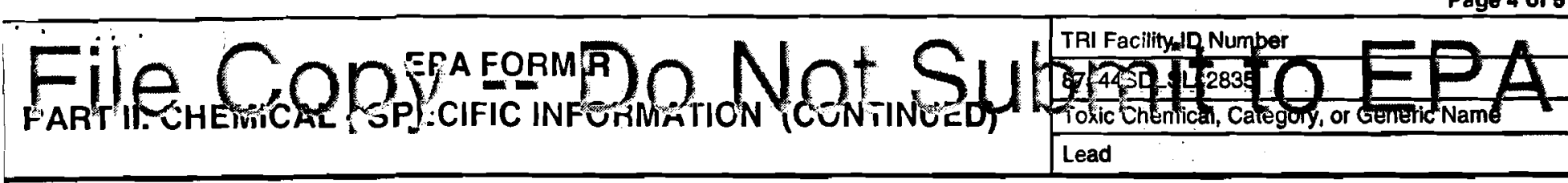

\section{SECTION 6.2 TRANSFERS TO OTHER OFF-SITE LOCATIONS (Continued)}

\begin{tabular}{|l|l|l|}
\hline $\begin{array}{l}\text { A. Total Transfers (pounds/year") } \\
\text { (enter range code*" or estimate) }\end{array}$ & $\begin{array}{l}\text { B. Basis of Estimate } \\
\text { (enter code) }\end{array}$ & $\begin{array}{l}\text { C. Type of Waste TreatmenvDisposal } \\
\text { Recyclling/Energy Recovery (enter code) }\end{array}$ \\
\hline 1. 31.2 & 1. & 1. M65 \\
\hline 2. NA & 2. & 2. \\
\hline 3. & 3. & 3. \\
\hline 4. & 4. & 4. \\
\hline
\end{tabular}

6.2. 2 OfH-Site EPA Identification Number (RCRA ID No.)

\begin{tabular}{l|l} 
Off-Site location Name & $\begin{array}{l}\text { Onyx Environmental Services } \\
\text { LLC. }\end{array}$ \\
\hline
\end{tabular}

\begin{tabular}{l|l}
\hline Off-site Address & 9131 East 96 th Avenue \\
\hline
\end{tabular}

\begin{tabular}{|l|l|l|l|l|l} 
City & Henderson & State & co & County & Denver \\
\hline
\end{tabular}

Is location under control of reporting facility or parent company?
A. Tōtal Tran̄s̄ers' (poünds/year")
(enter range code"* or estimate)
B. Basts of Estimate (enter code)
1. 1452.1
2. NA
1. 0
2.
3.
4.
3.
4.

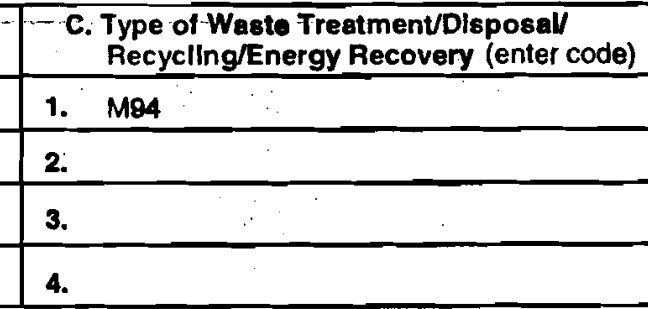

Recycling/Energy Recovery (enter code)

\begin{tabular}{|l|l|l|}
\hline Zlp & 80640 \\
\hline
\end{tabular}

Country

$\square$ Yes $\mathrm{X}$ No

$\square$ Yes $\mathrm{X}$ No

(Non-US)

SECTION 7A. ONSITE WASTE TREATMENT METHODS AND EFFICIENCY

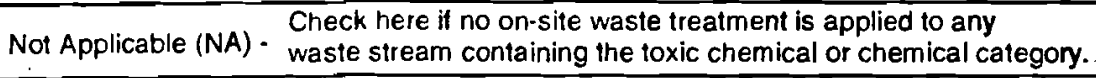

\begin{tabular}{l|l} 
a. General & b. Waste Treatment Method(s) Sequence
\end{tabular}

Waste Stream [enter 3-character code(s)]

(enter code)

\begin{tabular}{|c|c|c|c|c|}
\hline 7A.1a & 7A.1b & & \multirow{2}{*}{1} & \multirow{2}{*}{$\frac{\mathrm{H} 077}{\mathrm{NA}}$} \\
\hline \multirow{2}{*}{$\mathbf{W}$} & 3 & H129 & & \\
\hline & 6 & & 7 & \\
\hline \multirow[t]{3}{*}{ 7A.2a } & 7A.2b & & 1 & \\
\hline & 3 & & 4 & \\
\hline & 6 & & 7 & \\
\hline \multirow[t]{3}{*}{ 7A.3a } & 7A.3b & & 1 & \\
\hline & 3 & & 4 & \\
\hline & 6 & & 7 & \\
\hline \multirow[t]{3}{*}{$7 A .4 a$} & 7A.4b & & 1 & \\
\hline & 3 & & 4 & \\
\hline & 6 & & 7 & \\
\hline \multirow[t]{3}{*}{ 7A.5a } & $7 \mathrm{~A} .5 \mathrm{~b}$ & & 1 & \\
\hline & 3 & & 4 & \\
\hline & 6 & & 7 & \\
\hline
\end{tabular}

If additional pages of Part II, Section 6.2/7A are attached, indicate the total number of pages in this box

and indicate the Part II, Section 6.2/A page number in this box:

1 (example: $1,2,3$, etc.)

d. Waste Treatment Efficiency Estimate [enter 2 character code]

EPA Form 9350-1 (Rev. 8/2006) - Previous editions are obsolete.

- For Dioxin or Dioxin-like compounds, report in grams/year " Range Codes: $A=1-10$ pounds; $B=11-499$ pounds; $C=500-999$ pounds. 


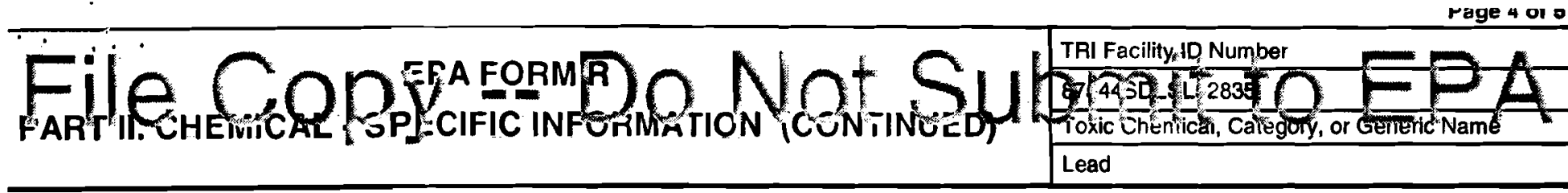

\section{SECTION 6.2 TRANSFERS TO OTHER OFF-SITE LOCATIONS (Continued)}

\begin{tabular}{l|l|l}
\hline $\begin{array}{l}\text { A. Total Transfers (pounds/year*) } \\
\text { (enter range code* or estimate) }\end{array}$ & \multicolumn{1}{|c|}{$\begin{array}{l}\text { B. Basis of Estimate } \\
\text { (enter code) }\end{array}$} & \multicolumn{1}{c}{$\begin{array}{l}\text { C. Type of Waste Treatment/sisposal } \\
\text { Recycling/Energy Recovery (enter code) }\end{array}$} \\
\hline 1. & 1. & 1. \\
\hline 2. & 2. & 2. \\
\hline 3. & 3. & 3. \\
\hline 4. & 4. & 4. \\
\hline 6.2 .3 & Off-Site EPA Identification Number (RCRA ID No.) & CAD008488025
\end{tabular}

\section{\begin{tabular}{|l|l}
\hline Off-Site location Name & Phibro Tech Inc. \\
\hline
\end{tabular}}

\section{\begin{tabular}{l|l} 
Off-site Address & 8851 Dice Road \\
\hline
\end{tabular}}

\begin{tabular}{l|l|l|l|l|l} 
City & Santa Fe Springs & State & CA & County & Los Angeles \\
\hline
\end{tabular} \begin{tabular}{ll|l|l} 
State & CA & County \\
\hline
\end{tabular}

(enter range code** or estimate)

1. 4.6

1. 4.6

2. NA

3.

4. (enter code)

\begin{tabular}{|l|l|c|} 
Zip & 90670 & $\begin{array}{c}\text { Country } \\
\text { (Non-US) }\end{array}$ \\
\hline
\end{tabular}

$$
\square \text { Yes }
$$

$\mathrm{X}$ No

C. Type of Waste TreatmentDisposal Recycling/Energy Recovery (enter code)

1. M24

2.

3.

4.

SECTION 7A. ONSITE WASTE TREATMENT METHODS AND EFFICIENCY

Wol Applicable (NA) - Check here if no on-site waste treatment is applied to any

Not Applicable (NA) - $\begin{aligned} & \text { Check here if no on-site waste treatment is applied to any } \\ & \text { wantaining the toxic chemical or chemical category. }\end{aligned}$

\begin{tabular}{|c|c|c|c|c|c|}
\hline $\begin{array}{l}\text { a. General } \\
\text { Waste Stream } \\
\text { (enter code) }\end{array}$ & \multicolumn{4}{|c|}{$\begin{array}{l}\text { b. Waste Treatment Method(s) Sequence } \\
\text { [enter 3-character code(s)] }\end{array}$} & \multirow{2}{*}{$\begin{array}{c}\text { d. Waste Treatment Efficiency Estimate } \\
\text { [enter } 2 \text { character code] }\end{array}$} \\
\hline $7 A .6 a$ & \multirow{3}{*}{\begin{tabular}{|c|}
$\mathrm{AA.6b}$ \\
3 \\
6 \\
\end{tabular}} & \multirow{3}{*}{$\begin{array}{l}1 \\
4 \\
7\end{array}$} & \multirow{3}{*}{$\begin{array}{l}2 \\
5 \\
8\end{array}$} & 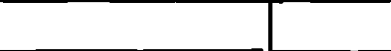 & \\
\hline \multirow{2}{*}{ (n) } & & & & & \\
\hline & & & & & \\
\hline \multirow{3}{*}{$7 A .7 a$} & 7A.7b & \multirow{3}{*}{$\begin{array}{l}1 \\
4\end{array}$} & \multirow{3}{*}{$\begin{array}{l}2 \\
5 \\
8\end{array}$} & & 7A.7d \\
\hline & \multirow{2}{*}{$\begin{array}{l}3 \\
6\end{array}$} & & & & \\
\hline & & & & & \\
\hline \multirow[t]{3}{*}{$7 A .8 \mathrm{a}$} & $7 \mathrm{A.8b}$ & 1 & \multirow{3}{*}{$\begin{array}{l}2 \\
5\end{array}$} & & 7A.8d \\
\hline & 3 & 4 & & & \\
\hline & 6 & 7 & & & \\
\hline \multirow[t]{3}{*}{$7 A .9 a$} & $7 \mathrm{~A} .9 \mathrm{~b}$ & \multirow[t]{3}{*}{1} & \multirow{3}{*}{$\begin{array}{l}2 \\
5 \\
8\end{array}$} & & 7A.9d \\
\hline & 3 & & & & \\
\hline & 6 & & & & \\
\hline \multirow{3}{*}{ 7A.10a } & 7A.10b & \multirow[t]{3}{*}{1} & \multirow{3}{*}{$\begin{array}{l}2 \\
5 \\
8\end{array}$} & & 7A.10d \\
\hline & \multirow{2}{*}{$\begin{array}{l}3 \\
6\end{array}$} & & & & \\
\hline & & & & & \\
\hline \multicolumn{5}{|c|}{ If additional pages of Part II, Section 6.2/7 A are attached, indicate the total number of pages in this box } & 6 \\
\hline \multicolumn{3}{|c|}{ and indicate the Part II, Section 6.27 A page number in this box: } & 2 & (example: $1,2,3$, etc.) & \\
\hline
\end{tabular}




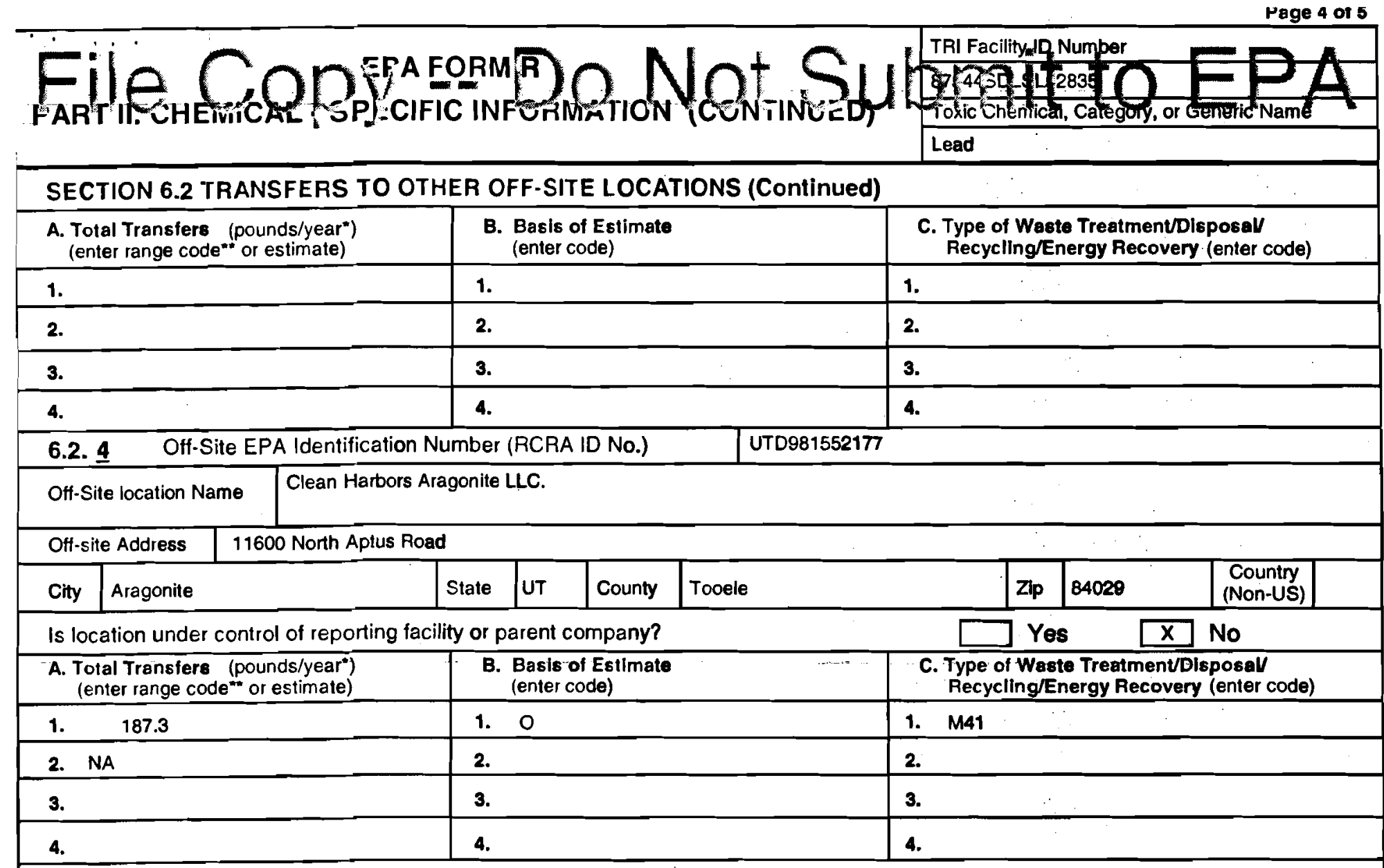

\section{SECTION 7A. ONSITE WASTE TREATMENT METHODS AND EFFICIENCY}

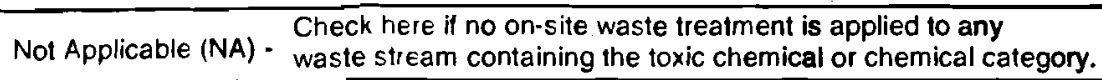

\begin{tabular}{|c|c|c|c|c|}
\hline \multirow{2}{*}{$\begin{array}{l}\begin{array}{l}\text { a. General } \\
\text { Waste Stream } \\
\text { (enter code) }\end{array} \\
\text { 7A.11a }\end{array}$} & \multicolumn{3}{|c|}{$\begin{array}{l}\text { b. Waste Treatment Method(s) Sequence } \\
\text { [enter 3-character code(s)] }\end{array}$} & \multirow{2}{*}{$\begin{array}{l}\text { d. Wasie Treatment Effici } \\
\text { [enter } 2 \text { character }\end{array}$} \\
\hline & 7A.11b & 1 & 2 & \\
\hline & 3 & 4 & 5 & \\
\hline & 6 & 7 & 8 & \\
\hline \multirow{3}{*}{ 7A.12a } & 7A.12b & \multirow{3}{*}{$\begin{array}{l}1 \\
4\end{array}$} & \multirow{3}{*}{$\begin{array}{l}2 \\
5 \\
8\end{array}$} & 7A.12d \\
\hline & 3 & & & \\
\hline & 6 & & & \\
\hline \multirow[t]{3}{*}{ 7A.13a } & $7 A .13 b$ & 1 & \multirow{3}{*}{$\begin{array}{l}2 \\
5 \\
8\end{array}$} & $7 A .13 d$ \\
\hline & 3 & 4 & & \\
\hline & 6 & 7 & & \\
\hline \multirow[t]{3}{*}{$7 A .14 a$} & 7A.14b & \multirow[t]{3}{*}{1} & \multirow{3}{*}{$\begin{array}{l}2 \\
5 \\
8\end{array}$} & 7A.14d \\
\hline & 3 & & & \\
\hline & 6 & & & \\
\hline \multirow{3}{*}{ 7A.15a } & $7 \mathrm{A.15b}$ & \multirow{3}{*}{$\begin{array}{l}1 \\
4\end{array}$} & \multirow{3}{*}{$\begin{array}{l}2 \\
5 \\
8\end{array}$} & 7A.15d \\
\hline & 3 & & & \\
\hline & 6 & & & \\
\hline
\end{tabular}

If additional pages of Part II, Section 6.2/7A are attached, indicate the total number of pages in this box and indicate the Part II, Section 6.2/7A page number in this box:

3 (example: $1,2,3$, etc.) 


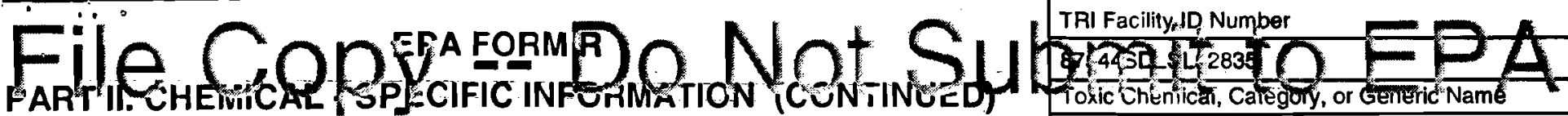 Lead}

\section{SECTION 6.2 TRANSFERS TO OTHER OFF-SITE LOCATIONS (Continued)}

\begin{tabular}{l|l|l}
\hline $\begin{array}{l}\text { A. Total Transfers (pounds/year*) } \\
\text { (enter range code" or estimate) }\end{array}$ & $\begin{array}{l}\text { B. Basis of Estimate } \\
\text { (enter code) }\end{array}$ & \\
\hline 1. & 1. & 1. \\
\hline 2. & 2. & 2. \\
\hline 3. & 3. & 3. \\
\hline 4. & 4. & 4 \\
\hline
\end{tabular}

C. Type of Waste Treatment/Disposal/ Recycling/Energy Recovery (enter code) 1.

2.

3.

4.

6.2. 7 Off-Site EPA Identification Number (RCRA ID No.)

UTD991301748

\begin{tabular}{l|l} 
Off-Site location Name & $\begin{array}{l}\text { Clean Harbors } \\
\text { Grassy Mount LLC. }\end{array}$ \\
\hline
\end{tabular}

\begin{tabular}{l|l} 
Off-site Address & Exit 41 Interstate 80 \\
\hline
\end{tabular}

\begin{tabular}{|l|l|l|l|l|l|l|l|l|l|} 
City & Grassy Mountain & State & UT & County & Tooele & Zip & 84029 & $\begin{array}{c}\text { Country } \\
\text { (Non-US) }\end{array}$ \\
\hline
\end{tabular}

Is location under control of reporting facility or parent company?

\begin{tabular}{|l|l|l}
$\begin{array}{l}\text { A. Total Transfers (pounds/year") } \\
\text { (enter range code }\end{array}$ & $\begin{array}{l}\text { B. Basis of Estimate } \\
\text { (enter code) }\end{array}$ & $\begin{array}{l}\text { C: Type-of Waste Freatment/Disposal } \\
\text { Recycling/Energy Recovery (enter code) }\end{array}$ \\
\hline 1. 485.2 & 1. O & 1. M79 \\
\hline 2. NA & 2. & 2. \\
\hline 3. & 3. & 3. \\
\hline 4. & 4. & 4. \\
\hline
\end{tabular}

SECTION 7A. ONSITE WASTE TREATMENT METHODS AND EFFICIENCY

Nol Applicable (NA) Check here if no on-site waste treatment is applied to any

waste stream containing the toxic chemical or chemical category.

\begin{tabular}{|c|c|c|c|c|}
\hline $\begin{array}{l}\text { a. General } \\
\text { Waste Stream } \\
\text { (enter code) }\end{array}$ & \multicolumn{3}{|c|}{$\begin{array}{l}\text { b. Waste Treatment Method(s) Sequence } \\
\text { [enter 3-character code(s)] }\end{array}$} & $\begin{array}{l}\text { d. Waste Treatment Efficie } \\
\text { |enter } 2 \text { character } c c\end{array}$ \\
\hline \multirow{3}{*}{ 7A.26a } & 7A.26b & \multirow{2}{*}{$\begin{array}{l}1 \\
4\end{array}$} & \multirow{2}{*}{$\begin{array}{l}2 \\
5\end{array}$} & \multirow[t]{3}{*}{$7 A .26 d$} \\
\hline & \multirow[t]{2}{*}{3} & & & \\
\hline & & 4 & 8 & \\
\hline \multirow{3}{*}{ 7A.27a } & 7A.27b & 1 & \multirow{3}{*}{$\begin{array}{l}2 \\
5 \\
8\end{array}$} & \multirow[t]{3}{*}{ 7A.27d } \\
\hline & \multirow[t]{2}{*}{3} & \multirow[t]{2}{*}{4} & & \\
\hline & & & & \\
\hline \multirow{3}{*}{ 7A.28a } & $7 A .28 b$ & 1 & \multirow{3}{*}{$\begin{array}{l}2 \\
5\end{array}$} & $7 \mathrm{~A} .28 \mathrm{~d}$ \\
\hline & \multirow[t]{2}{*}{3} & \multirow[t]{2}{*}{4} & & \multirow[t]{2}{*}{. } \\
\hline & & & & \\
\hline \multirow{3}{*}{ 7A.29a } & $7 A .29 b$ & \multirow[t]{3}{*}{1} & \multirow{3}{*}{$\begin{array}{l}2 \\
5\end{array}$} & \multirow[t]{3}{*}{ 7A.29d } \\
\hline & \multirow[t]{2}{*}{3} & & & \\
\hline & & & & \\
\hline \multirow[t]{3}{*}{ 7A.30a } & 7A.30b & \multirow[t]{3}{*}{1} & \multirow{3}{*}{$\begin{array}{l}2 \\
5\end{array}$} & \multirow[t]{3}{*}{ 7A.30d } \\
\hline & 3 & & & \\
\hline & 6 & & & \\
\hline
\end{tabular}

If additional pages of Part II, Section 6.2/7A are altached, indicate the total number of pages in this box

and indicate the Part II, Section 6.2ПA page number in this box:

6 (example: $1,2,3$, etc.)

EPA Form 9350-1 (Rev. 8/2006) - Previous editions are obsolete.

- For Dioxin or Dioxin-like compounds, report in grams/year " Range Codes: $A=1-10$ pounds; $B=11-499$ pounds; $C=500-999$ pounds. 


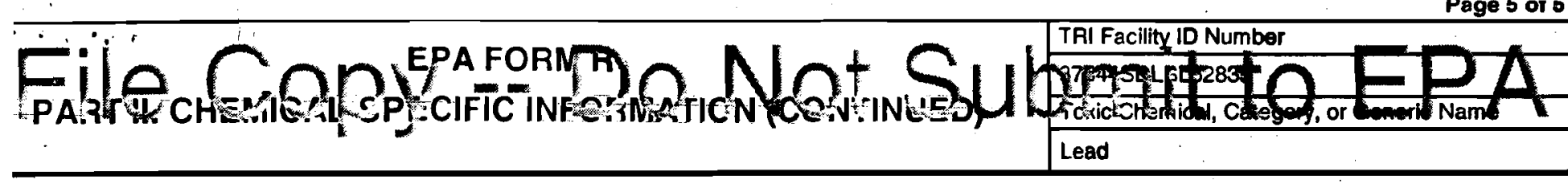

\section{SECTION 7B. ON-SITE ENERGY RECOVERY PROCESSES}

X Not Applicable (NA) - $\begin{aligned} & \text { Check here if no on-site energy recovery is applied to any waste } \\ & \text { stream containing the toxic chemical or chemical category. }\end{aligned}$

Energy Recovery Methods [enter 3-character code(s)]

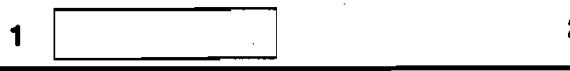

2

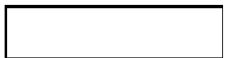

3

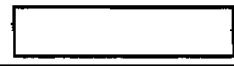

\section{SECTION 7C. ON-SITE RECYCLING PROCESSES}

X Not Applicable (NA) - $\begin{aligned} & \text { Check here if no on-site recyling is applied to any waste } \\ & \text { stream containing the toxic chemical or chemical category }\end{aligned}$

Recycling Methods [enter 3-character code(s)]

1

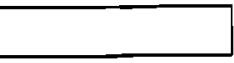

2

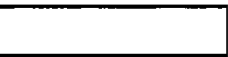

s

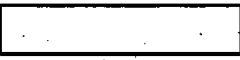

\section{SECTION 8. SOURCE REDUCTION AND RECYCLING ACTIVITIES}

\begin{tabular}{|c|c|c|c|c|c|}
\hline & & $\begin{array}{l}\text { Column A } \\
\text { Prior Year }\end{array}$ & \multirow{2}{*}{$\begin{array}{c}\text { Column B } \\
\text { Current Reporting Year } \\
\text { (pounds/year) } \\
\end{array}$} & $\begin{array}{l}\text { Column C } \\
\text { Following Year }\end{array}$ & $\begin{array}{l}\text { Column D } \\
\text { Second Following_Year }\end{array}$ \\
\hline \multicolumn{2}{|c|}{ 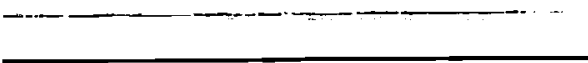 } & (pounds/year) & & (pounds/yeari) & (pounds/year) \\
\hline 8.1 & & \multicolumn{4}{|c|}{ 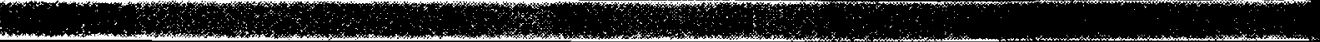 } \\
\hline 8.1a & $\begin{array}{l}\text { Total on-site disposal to Class I } \\
\text { Underground Injection Wells, RCRA } \\
\text { Subtitle C landfills, and other landfilts }\end{array}$ & NA & NA & NA & NA \\
\hline $8.1 \mathrm{~b}$ & $\begin{array}{l}\text { Total other on-site disposal or other } \\
\text { releases }\end{array}$ & 7556.4 & 8890.57 & 9000 & 9000 \\
\hline $8.1 \mathrm{C}$ & $\begin{array}{l}\text { Total off-site disposal to Class I } \\
\text { Underground Injection Wells, RCRA } \\
\text { Subtitle C landfills, and other landfills }\end{array}$ & NA & 34.4 & 30 & 30 \\
\hline 8.1d & $\begin{array}{l}\text { Total other off-site disposal or other } \\
\text { releases }\end{array}$ & 1151 & 2139.1 & 4000 & 4000 \\
\hline 8.2 & $\begin{array}{l}\text { Quantity used for energy recovery } \\
\text { onsite }\end{array}$ & NA & NA & NA & NA \\
\hline 8.3 & $\begin{array}{l}\text { Quantity used for energy recovery } \\
\text { offsite }\end{array}$ & NA & NA & NA & NA \\
\hline 8.4 & Quantity recycled onsite & NA & NA $\cdots$ & NA & NA \\
\hline 8.5 & Quantity recycled offsite & 326 & 4.6 & 50 & 50 \\
\hline 8.6 & Quantity treated onsite & NA & NA & NA & NA \\
\hline 8.7 & Quantity treated offsite & NA & NA & NA & NA \\
\hline 8.8 & \multicolumn{3}{|c|}{$\begin{array}{l}\text { Quantity released to the environment as a result of remedial actions, catastrophic events, } \\
\text { or one-time events not associated with production processes (pounds/year) }\end{array}$} & \multicolumn{2}{|l|}{ NA } \\
\hline 8.8 & \multicolumn{3}{|l|}{ Production ratio or activity index } & \multicolumn{2}{|l|}{1.36} \\
\hline \multirow[b]{2}{*}{8.10} & \multicolumn{5}{|c|}{$\begin{array}{l}\text { Did your facility engage in any source reduction activities for this chemical during the reporting year? lf not, } \\
\text { enter "NA" in Section 8.10.1 and answer Section 8.11. }\end{array}$} \\
\hline & $\begin{array}{l}\text { Source Reduction Activities } \\
\text { [enter } \operatorname{code}(\mathbf{s})]\end{array}$ & \multicolumn{3}{|c|}{ Methods to Identify Activity (enter codes) } & \\
\hline 8.10 .1 & NA & a. & b. & & c. \\
\hline 8.10 .2 & & a. & b. & & c. \\
\hline 8.10 .3 & & a. & b. & & c. \\
\hline 8.10 .4 & & a. & b. & & c. \\
\hline 8.11 & $\begin{array}{l}\text { If you wish to submit additional optiona } \\
\text { pollution control activities with this repo }\end{array}$ & $\begin{array}{l}\text { nformation on source re } \\
\text { check "Yes." }\end{array}$ & uction, recycling, or & & Yes \\
\hline
\end{tabular}



This report has been reproduced directly from the best available copy. It is available electronically on the Web (http://www.doe.gov/bridge).

Copies are available for sale to U.S. Department of Energy employees and contractors from:

Office of Scientific and Technical Information

P.O. Box 62

Oak Ridge, TN 37831

(865) 576-8401

Copies are available for sale to the public from: National Technical Information Service

U.S. Department of Commerce

5285 Port Royal Road

Springfield, VA 22161

(800) 553-6847 
- Los Alamos NATIONAL LABORATORY

EST.1943 